\title{
Genetics and Function of Neocortical GABAergic Interneurons in Neurodevelopmental Disorders
}

\author{
E. Rossignol ${ }^{1,2}$ \\ ${ }^{1}$ Department of Pediatrics, Neurology, Sainte-Justine Hospital and Research Center, 3175 Chemin de la Côte Sainte-Catherine, \\ Montreal, QC, Canada H3T 1 C5 \\ ${ }^{2}$ Department of Pediatrics, Brain Disease Research Group, Sainte-Justine Hospital and Research Center, \\ 3175 Chemin de la Côte Sainte-Catherine, Montreal, QC, Canada H3T 1C5
}

Correspondence should be addressed to E. Rossignol, elsa.rossignol@umontreal.ca

Received 28 February 2011; Accepted 4 May 2011

Academic Editor: Graziella Di Cristo

Copyright ( $) 2011$ E. Rossignol. This is an open access article distributed under the Creative Commons Attribution License, which permits unrestricted use, distribution, and reproduction in any medium, provided the original work is properly cited.

A dysfunction of cortical and limbic GABAergic circuits has been postulated to contribute to multiple neurodevelopmental disorders in humans, including schizophrenia, autism, and epilepsy. In the current paper, I summarize the characteristics that underlie the great diversity of cortical GABAergic interneurons and explore how the multiple roles of these cells in developing and mature circuits might contribute to the aforementioned disorders. Furthermore, I review the tightly controlled genetic cascades that determine the fate of cortical interneurons and summarize how the dysfunction of genes important for the generation, specification, maturation, and function of cortical interneurons might contribute to these disorders.

\section{Introduction}

The exquisite complexity of cognitive functions stems from tightly regulated interactions between distributed cortical networks performing precise neural computations. GABAergic inhibitory interneurons (INs), which represent a minority of neocortical neurons (20\% in rodents [1]), play a crucial role in these cortical circuits. GABAergic INs shape the responses of pyramidal cells to incoming inputs, prevent runaway excitation, refine cortical receptive fields, and are involved in the timing and synchronisation of population rhythms expressed as cortical oscillations [2-9]. Consequently, disruption of cortical GABAergic IN function has been linked to various neurodevelopmental disorders, including epilepsy, mental retardation, autism, and schizophrenia [10-15].

Cortical INs are diverse in terms of their anatomical laminar distribution, histochemical marker expression, intrinsic physiological properties, and connectivity (Figure 1) [5, 6, 9, 16-22]. This heterogeneity is characterized by the expression of specific combinations of ion channels, receptors, and membrane cell adhesion molecules [7]. These specific protein expression profiles are the result of tightly controlled genetic pathways that regulate cortical IN identity [8, 23-29]. Anomalies in these genetic pathways might therefore underlie some of the neurodevelopmental and neurocognitive disorders seen in humans. In the current paper, I will give an overview of cortical IN diversity, summarise the various roles of cortical INs in neuronal circuit development and function, review the genetic pathways involved in specifying cortical GABAergic IN diversity, and explore the pathological correlates of genetic anomalies leading to interneuron dysfunction in rodents and humans. As the current paper focuses on neocortical INs, readers are directed to other sources for a broader description of other GABAergic populations, including those of the amygdala, striatum, hippocampus, thalamus, and olfactory bulbs, which also participate in the corticolimbic and corticosubcortical circuits involved in cognition and emotional processing [7, 30-40].

1.1. Diversity of Cortical GABAergic Interneurons Subtypes and Roles. Neocortical GABAergic INs are heterogeneous, and different subtypes of INs have different spatial and temporal origins. As a group, neocortical INs are derived from transient ventral telencephalic structures referred to as the 


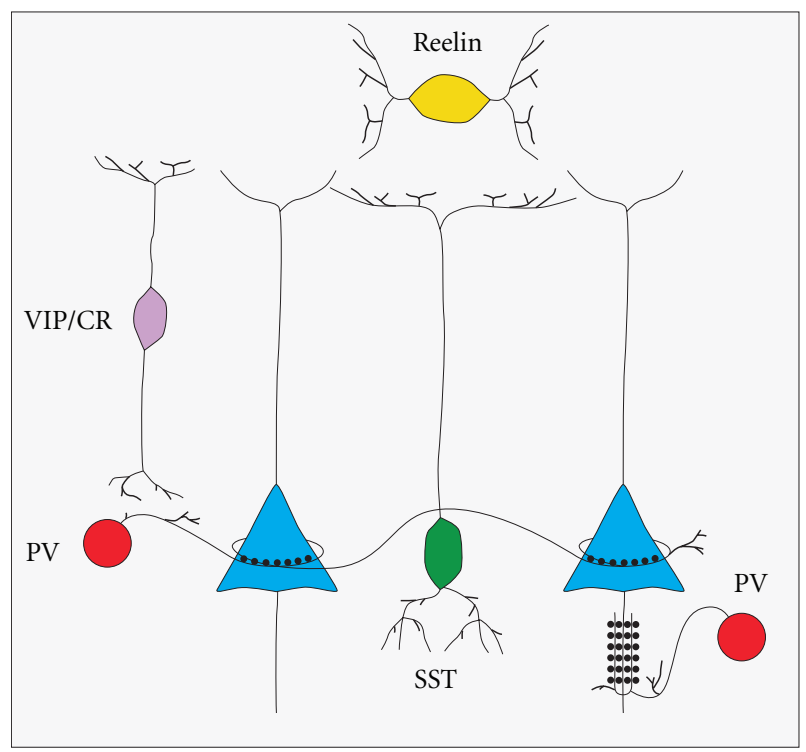

Figure 1: Interneuron diversity. Interneurons are diverse in terms of their histochemical profile, morphology, physiological properties, and connectivity. In this schematic representation, parvalbumin-positive (PV) interneurons (red) include basket cells forming perisomatic contacts on adjacent pyramidal cells (dark blue), as well as chandelier cells that target the pyramidal cell axon initial segment. Somatostatinpositive (SST) interneurons include Martinotti cells that contact pyramidal cell dendrites in layer I. Vasointestinal peptide (VIP) and calretinin (CR) double-positive bitufted interneurons target pyramidal cells and other interneurons. Neurogliaform cells, marked with reelin, are the most abundant interneurons in layer I and provide tonic GABAergic inhibition via volume transmission of GABA.

ganglionic eminences $[27,29,41-46]$ as well as from the preoptic area [47]. The medial ganglionic eminence (MGE) produces approximately $70 \%$ of neocortical INs, including the parvalbumin-positive (PV) fast-spiking interneurons and the somatostatin-positive (SST) interneurons, which represent $40 \%$ and $30 \%$ of all neocortical INs, respectively $[27,46,48]$. By contrast, the caudal ganglionic eminence (CGE) gives rise to the remaining $30 \%$ of neocortical INs, a more heterogeneous group of cortical INs that share the unique expression of 5HT3A ionotropic serotoninergic receptors, rendering them highly responsive to the neuromodulatory effects of serotonin [9, 43, 46, 48, 49]. A majority of CGE-derived interneurons belong to either the reelinpositive multipolar population (including the late-spiking neurogliaform cells), the vasointestinal-peptide- (VIP-) positive bitufted population (including a calretinin- (CR)positive population), or the VIP-positive, calretinin-negative bipolar population. Finally, the preoptic area contributes a small portion of neocortical INs $(<3 \%)$ that are not labelled by the usual interneuron markers mentioned above [47]. The lateral ganglionic eminence (LGE) mainly produces olfactory bulb and amygdalar INs, as well as striatal and nucleus accumbens medium spiny neurons, but is generally thought not to give rise to cortical INs $[23,33,38,41,50,51]$. Different subtypes of cortical INs are identified based on their immunohistochemical, morphological, physiological, and connectivity properties, and they mediate different functions in mature networks as detailed below.

1.2. Parvalbumin-Positive Basket Cells. PV-positive interneurons include the perisomatically targeting basket cells and the less abundant axon-initial segment-targeting chandelier cells. PV-positive basket cells can be further divided according to various morphological characteristics, including somatic diameter, firing properties, and extent of dendritic and axonal arborisation [5, 9, 52, 53]. As a group, PVpositive basket cells display many characteristics which render them one of the fastest and most reliable sources of inhibition in the cortex. They exhibit low input resistance, fast membrane kinetics, brief action potentials with large afterhyperpolarisation, and minimal spike adaptation and are able to sustain high frequency firing rates $[5,18,19$, $21,44,52,54]$. These fast kinetics are partly due to their expression of Kv3 voltage-gated potassium channels [52, 5559], which ensure quick repolarisation and termination of action potentials. In addition, PV-positive fast-spiking cells mediate fast reliable neurotransmission, as they rely mainly on $\mathrm{P} / \mathrm{Q}$-type presynaptic $\mathrm{Ca}^{2+}$ channels for tight coupling between action potentials and neurotransmitter release [6063]. Furthermore, these PV-positive basket cells might be able to buffer calcium more efficiently, as they express high levels of $\mathrm{Ca}^{2+}$-binding proteins, including parvalbumin and calbindin. It is possible that this expression of $\mathrm{Ca}^{2+}$-binding proteins renders these cells more resistant to $\mathrm{Ca}^{2+}$-induced excitotoxicity in the face of high firing rates.

PV-positive INs are the main inhibitory target of thalamocortical projections in the cortex. In addition, PV-positive basket cells form intricate nests of synaptic contacts on the soma of adjacent pyramidal cells, giving them rapid control over the excitability of their pyramidal cell targets. These INs are therefore well positioned to provide strong and fast feedforward inhibition to adjacent pyramidal cells, limiting 
the time window for temporal summation of excitatory inputs and spike generation within populations of pyramidal cells. This feature sharpens the cortical response and prevents runaway excitation following thalamocortical excitation [6468].

In addition, PV-positive basket cells are highly interconnected with one another through both chemical and electric synapses (gap junctions), creating a vast web of synchronously active INs $[69,70]$. This network of inhibitory INs triggers and maintains high-frequency gamma oscillations within ensembles of cortical pyramidal cells [69, 7177]. In support of this, the loss of connexin32, which forms gap junction connections between PV-positive INs, results in the partial loss of task-induced gamma oscillations [78]. Gamma oscillations are important for the maintenance of attention, working memory, and the refinement of executive functions in humans and rodents [79-83]. Therefore, PVpositive interneuron dysfunction has been postulated to underlie the loss of gamma oscillations in schizophrenic patients displaying working memory and executive function abnormalities [14, 82, 84, 85].

\subsection{Parvalbumin-Positive Chandelier Cells. Like PV-positive} basket cells, PV-positive chandelier cells display brief nonadapting trains of action potentials upon stimulation and are able to sustain high frequency firing rates $[17,86,87]$. They are characterised morphologically by their cartridges of vertically oriented candlestick-like axonal arbors [8890]) forming synapses on the axon initial segment (AIS) of pyramidal cells $[89,91]$. Chandelier cells are unusual among interneurons in that their output has been postulated to be excitatory rather than inhibitory. Indeed, the stimulation of chandelier cells triggers depolarisations in target pyramidal cells in the cortex and dentate gyrus [92-95]. This has been attributed to the high concentration of chloride and elevated $\mathrm{GABA}_{\mathrm{A}}$ reversal potential at the AIS, due to efficient $\mathrm{Cl}^{-}$ import by the NKCC1 transporter in the absence of the KCC2 transporter (see below) [92, 93]. However, it is still unclear whether such depolarizing responses are obligatorily excitatory [95]. Furthermore, in other circuits, such as in the CA1 region of the hippocampus, chandelier cells appear to trigger hyperpolarising responses [96]. Overall, the net effect of chandelier cells might be dependent on the local state of network activity and on the particular ion channel composition of local pyramidal cells in different brain regions. In vivo, chandelier cells might be involved in the generation of specific oscillatory activities as they fire immediately before hippocampal pyramidal cells during sharp-wave-associated ripples [97].

\subsection{Somatostatin-Positive (SST) Interneurons. Somatostatin-} positive interneurons, including Martinotti cells and nonMartinotti cells, are heterogeneous in terms of their immunohistochemical profile (variable colabelling with calretinin and calbindin), morphology (multipolar, bipolar, or unipolar), axonal projections (most target pyramidal cell dendrites in layer I but some project locally within their cortical layer), and intrinsic electrophysiological properties $[9,45,98-100]$. A majority of SST interneurons (including the Martinotti cells) share some physiological characteristics, including a low spike threshold, prominent afterhyperpolarisation, and spike rate adaptation. However, these cells differ in their spiking pattern at threshold (regular versus bursting), especially when fired from hyperpolarized step currents [17, 98, 99]. In general, compared to fastspiking basket cells, SST-positive interneurons tend to be more excitable: they display a lower spike threshold and have a higher resting membrane potential [101]. One exception to this rule is a population of non-Martinotti cells, which have a high firing threshold, higher firing rate, shorter spike half width, and lower input resistance $[45,99]$. These cells have been mostly described in layer 4 of the cortex and are preferentially labelled in the X94 GAD67-GFP transgenic line $[9,99]$.

SST-positive Martinotti cells are found across cortical layers II-VI but are most abundant in cortical layer V. They project vertically towards layer I where they contact pyramidal cell dendrites and extend multiple axonal collaterals towards adjacent cortical columns [19, 102, 103]. Martinotti cells regulate pyramidal cell excitability by controlling the dendritic summation and integration of synaptic inputs and sharpening the coding of stimulus intensity [104]. Furthermore, as their connectivity is simultaneously divergent, convergent, and recurrent, they mediate disynaptic inhibition between interconnected pyramidal cells as well as recurrent feedback inhibition onto presynaptic pyramidal cells $[105,106]$. They are therefore well suited to prevent excessive and recurrent excitation within cortical networks. Furthermore, they are increasingly recruited by sustained stimulation, owing to the fact that the synapses that they receive from pyramidal cells are in most cases facilitating $[101,107]$. This renders them good candidates to dampen excitation during high activation states. Dysfunction of somatostatin cells has therefore been postulated to underlie some forms of experimental or poststatus epilepticus seizure disorders [108].

Because of their expression of low-threshold voltagegated calcium channels and persistent sodium currents, about $40 \%$ of SST cells display intrinsic bursting abilities and might act as pacemaker cells, thereby triggering particular cortical oscillations [224]. Indeed, SST-positive cells, which are highly interconnected via gap junctions, tend to oscillate spontaneously in the theta range $(3-9 \mathrm{~Hz})$ when stimulated electrically or with cholinergic agonists in vitro [101]. They could therefore be involved in pacing cortical pyramidal cells in the theta range.

1.5. Vasoactive Intestinal Peptide- (VIP-) Positive Interneurons. CGE-derived interneurons tend to populate more superficial cortical layers than MGE-derived interneurons. Approximately $40 \%$ of CGE INs express VIP, and these cells tend to be enriched in layers II/III [19, 46, 48, 225, 226]. VIPpositive INs are diverse morphologically, histochemically, and physiologically [9]. The most abundant type are the bitufted VIP+ INs that tend to colabel with CR $[46,48]$, display an irregular-spiking firing pattern near threshold $[18,46,48,49,227]$, and send a downward projecting axon towards deeper cortical layers. The second most abundant 
type is the VIP+, CR- bipolar cells, which display a fast adapting firing pattern $[44,46,48,227]$ and send extensively branched projections both locally and towards deep cortical layers. Due to their high input resistance, VIP INs tend to be highly excitable $[18,46,48]$. They have been shown to target pyramidal cell dendrites and somata [17], but some subsets appear to target other interneurons more preferentially [228-230]. The precise function of VIP interneurons in cortical networks remains to be determined. However, their physiological characteristics and diverse synaptic targets render them well suited to rapidly modulate the interactions between pyramidal cells and MGE-derived interneurons. Furthermore, as they receive strong input from pyramidal cells in layers II-III [231], which also receive input from pyramidal cells in other functionally connected cortical areas, VIP interneurons might be important in regulating cross-cortical communication (i.e., sensorimotor modulation where inputs from the sensory cortex modulate the output of cortical motoneurons).

1.6. Neurogliaform Cells. Neocortical neurogliaform cells exist in all cortical layers but are the most abundant GABAergic population in superficial layer I $[46,48]$. They express reelin (as well as alpha actinin 2 in the rat $[103,232]$ ), but not VIP or SST $[9,46]$. They are morphologically distinct as they have multiple radially oriented dendrites extending from a small round soma, as well as a finely branched dense axonal plexus typically extending well beyond the dendritic tree, giving them a spider web appearance [19, 233]. Neurogliaform cells display late-spiking firing patterns with spike accommodation during sustained depolarisations $[19,44,45,48,234]$. They have been shown to elicit slow long-lasting inhibitory events (IPSPs) in pyramidal cells and other interneurons by activating both $\mathrm{GABA}_{\mathrm{A}}$ and $\mathrm{GABA}_{\mathrm{B}}$ receptors after nonsynaptic volume release of GABA [233235]. Some of this tonic inhibition is thought to be mediated through the activation of delta subunit-containing $\mathrm{GABA}_{\mathrm{A}}$ receptors, which are modulated by neurosteroids [235]. This effect might underlie the antiepileptic effect of steroids used to treat pharmacoresistant epilepsies [236, 237]. Furthermore, neurogliaform cells are extensively interconnected by electrical gap-junction synapses but also contact most other interneurons subtypes via similar electrical synapses [238240]. They are therefore well suited to shape synchronous cortical oscillations. Finally, some neurogliaform cells release nitric oxide, a potent vasodilator, and may therefore play a role in the neurovascular adjustment of blood flow in the face of cerebral hypoperfusion (i.e., strokes, shock, etc.) $[241,242]$.

\section{The Development of Cortical Interneurons Depends on Tightly Regulated Genetic Cascades}

Cortical interneurons originate in the ventricular zone of the ventral telencephalic ganglionic eminences [41, 43, $243]$, migrate tangentially up to the cortex [218, 244], and reach their final destination after radial migration across cortical layers. This is quite distinct from cortical pyramidal cells, which originate from the cortical ventricular zone, migrate radially, and reach their final position after a brief bout of tangential migration [42, 245]. The ganglionic eminences are divided into three different subdomains, the medial (MGE), caudal (CGE), and lateral (LGE) ganglionic eminences, which produce distinct subtypes of interneurons in a temporally dynamic fashion $[44-46,246]$. Cortical interneurons originate from the MGE and CGE [41, 43, 243], as well as from the preoptic area [47]. Although this has been debated, it is generally believed that the LGE does not give rise to cortical interneurons, instead generating medium spiny neurons of the striatum, nucleus accumbens, and olfactory tubercules, as well as olfactory bulb and amygdalar interneurons $[23,33,38,41,50,51]$.

The genetic code that governs the generation and specification of cortical interneurons has been extensively studied over the last decade (Figure 2). The Dlx homeobox genes, including $D l \times 1 / 2$ and $D l \times 5 / 6$, encode a family of transcription factors crucial for the generation, specification, and migration of all interneurons. The proneural gene mammalian achaete-scute homolog 1 (Mash1), which encodes a basic helix-loop-helix transcription factor, is also crucial for these processes. These genes are broadly expressed across the subpallial subventricular zone (SVZ) of the ganglionic eminences [218, 247-249]. In mice carrying compound Dlx 1 and $D l \times 2$ knock-out mutations, GABAergic interneurons fail to migrate out of the ganglionic eminences, resulting in striking reductions in cortical and olfactory bulb interneurons as well as abnormal striatal differentiation [23, 219]. Similar results are seen in mice lacking Mash1 [250]. Interestingly, $D l \times 1 / 2$ gene dosage appears to be important, as interneurons in mice carrying a $D l \times 1^{-/-} ; D l \times 2^{+/-}$genotype displays normal tangential migration to the cortical plate, but shows altered laminar positioning and simplified morphology (long axons and dendrites with few branches) [220]. Furthermore, $D l x 1^{-/-}$mutants display selective defects in the dendritic morphology of SST+/CR+ interneurons, with a progressive loss of these interneurons in the postnatal brain, resulting in spontaneous seizures [221].

The MGE and CGE give rise to distinct cortical interneuronal populations $[25,41]$. The MGE generates the parvalbumin-positive (fast-spiking basket cells and chandelier cells) and somatostatin-positive interneurons (including Martinotti cells) $[8,9,22,25,41,44,45,251]$. The specification of these interneurons relies on the expression of NK2 homeobox 1 (Nkx2-1) [22, 222]. The loss of Nkx2-1 as interneuron progenitors are exiting their last mitotic division in the ganglionic ventricular zone leads to respecification of these cells into CGE-type interneurons (of all major subtypes) and the consequent absence of cortical PV and SST interneurons [22]. Interestingly, PV interneurons originate mainly from the ventral MGE whereas SST cells are preferentially produced by the dorsal MGE $[251,252]$, a phenomenon likely mediated by the combinatorial expression of particular transcription factors within different subdomains of the MGE [252, 253], resulting in part from a gradient of SHH expression [254]. Furthermore, a portion of the dorsal MGE and the MGE-CGE sulcus region is delineated by the 


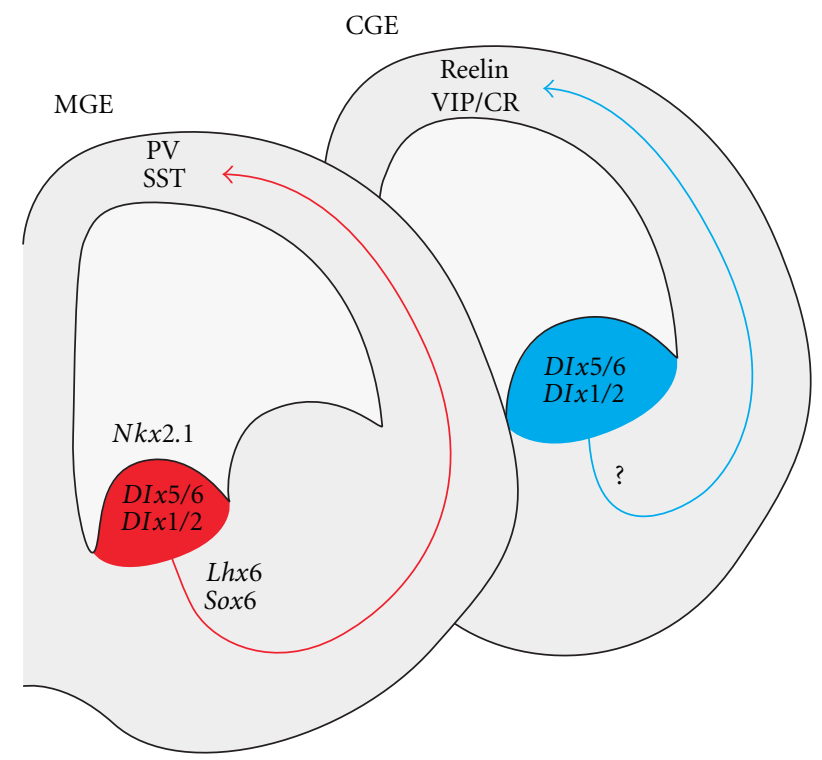

FIGURE 2: Genetic cascade governing cortical interneuron generation. Corticolimbic interneurons originate in the medial and caudal ganglionic eminences (MGE and CGE). The homeobox transcription factors Dlx5/6,Dlx1/2 and the proneural gene Mash1 (not shown) are expressed throughout the ganglionic eminences and are required for the generation of all GABAergic interneurons. The MGE generates parvalbumin-positive (PV) basket cells and chandelier cells, as well as somatostatin-positive (SST) cells (including Martinotti cells). These rely on the sequential expression of $N k x 2.1, L h x 6$, and Sox 6 for proper specification and maturation (see text). The genetic cascade governing the specification of CGE-derived interneurons has not been fully elucidated yet, but Nkx6.2 and Gsh2 are expressed in the CGE and might be important players (see text).

expression of the homeodomain transcription factor $N k x 6-2$, which partially overlaps with $N k x 2-1$. This area gives rise to the subgroup of somatostatin cells (about 30\%) that coexpress somatostatin and calretinin and display a delayed nonfast spiking firing pattern $[251,255]$.

As they leave the ventricular zone, MGE-derived interneurons begin to express the transcription factor LIM homeobox protein 6 (Lhx6), which is expressed into adulthood [26, 222, 251, 256, 257]. Lhx6 is required for proper specification and migration of MGE-derived interneurons, and the loss of $\operatorname{Lh} x 6$ results in misspecified hippocampal and cortical INs. These cells retain their GABAergic identity, but they fail to express PV or SST and are mislocalised within the neocortex [257]. Indeed, Lhx6 loss disrupts the correct expression of downstream effectors known to be important for IN migration, including $v$-erb-a erythroblastic leukemia viral oncogene homolog 4 (ErbB4), C-X-C chemokine receptor type 4 (CXCR4) and type 7 (CXCR7), and aristaless-related homeobox $(A R X)[26,258]$.

Downstream of Lhx6 is SRY-box 6 (Sox6), another transcription factor expressed by MGE-derived interneurons as they initiate their tangential migration. Sox6 is required for the proper laminar distribution and maturation of MGEderived interneurons [28]. Its loss results in mislocalised MGE-derived INs that accumulate ectopically in layer I and deep layer VI, failing to adequately populate cortical layers II-V [28, 223]. Furthermore, these cells fail to express their mature markers, leading to a striking loss of cortical PV- and SST-expressing cells (PV being more severely affected). Although they remain correctly specified as MGEINs, as evidenced by their morphology, electrophysiological properties, and expression of GABA, the resulting mutant cells fail to acquire mature intrinsic properties. For instance, $\mathrm{PV}$-cells are unable to sustain the high frequency firing rates expected from these cells by P17-18 [28]. This results in a severe developmental epileptic encephalopathy with early lethality during the 3 rd postnatal week [28].

As detailed above, the CGE produces a great variety of cortical interneurons, which populate the more superficial cortical layers. CGE-derived INs include all VIP- and reelin-positive cells, including the calretinin bipolar and neurogliaform cells, as well as multiple smaller subgroups of cortical interneurons, which are distinguishable by their morphological and physiological properties [25, 43, 44, 46]. The master regulatory genes for CGE cell-fate determination have yet to be fully determined. However, some transcription factors are expressed in both the CGE and dorsal MGE, including Nkx6-2 and CoupTF1/2, and might play a role in the specification of CGE interneurons [255].

\section{GABAergic Interneurons Play Fundamental Roles in Developing Circuits}

GABA signalling is crucial during embryogenesis for both neural and nonneural populations of cells [259]. In fact, early GABAergic signalling has been shown to affect neurogenesis, differentiation, migration, and integration of developing neurons into neuronal circuits $[260,261]$. Indeed, GABA receptors are expressed early in newborn pyramidal neurons, which receive GABAergic inputs long before forming excitatory synapses $[262,263]$. GABA is excitatory in immature 
neurons due to the high level of NKCC1 expression. NKCC1 increases the intracellular concentration of $\mathrm{Cl}^{-}$, shifting the GABA equilibrium potential $\left(\mathrm{E}_{\mathrm{GABA}}\right)$ to more depolarised levels, thereby leading to an extrusion of negatively charged chloride anions upon activation of $\mathrm{GABA}_{\mathrm{A}}$ receptors and a depolarisation of the cell membrane [264]. With time, the progressive expression of another chloride transporter, KCC2, lowers the baseline intracellular concentration of $\mathrm{Cl}^{-}$and underlies the developmental switch of $\mathrm{E}_{\mathrm{GABA}}$ in favour of an inhibitory effect of GABA in mature neurons $[265,266]$.

This developmental switch is important in controlling the migration, final position, and morphological maturation of interneurons. Tangentially migrating interneurons have been shown to release GABA in a nonvesicular manner [267]. GABA then acts synergistically with AMPA/NMDA receptor-mediated currents to promote tangential migration of interneurons as long as it is depolarising. However, the gradual expression of KCC2 shifts the reversal potential of GABA and the resulting hyperpolarisation acts as a stop signal to arrest the migration of cortical interneurons [268]. Interestingly, interneurons derived from the MGE, which reach their final layer earlier than CGE-derived interneurons, also appear to express KCC2 earlier than CGE cells born simultaneously [246]. KCC2 might therefore regulate some of the differences observed in the laminar distribution of interneurons originating from different sources.

Furthermore, GABA-mediated depolarisations have recently been shown to promote excitatory synapse formation by facilitating NMDA receptor activation in cortical pyramidal neurons [269]. Blocking these GABA-mediated depolarisations, by in utero knock-down of NKCC1 or with the NKCC1 antagonist bumetanide, results in decreased numbers of functional excitatory synapses [269]. These manipulations also lead to altered cell morphologies, including thinner apical dendrites, simplified dendritic trees, and decreased dendritic spine densities [269]. These detrimental effects of bumetanide appear to be long-lasting, as they persist in the adult cortex and are associated with developmental delay and altered prepulse inhibition in adult mice [270]. Premature overexpression of KCC2 leads to similar dendritic anomalies in cortical pyramidal cells as those reported after blocking NKCC1 [271].

In summary, GABA plays fundamental roles at different stages of neuronal development, affecting migration, maturation, and synapse formation of both pyramidal cells and interneurons. Furthermore, the precise effect of GABA postsynaptically is dependent on the intracellular concentration of chloride, which is developmentally regulated via the expression of various chloride cotransporters and which varies depending on the age of the cells.

\section{Interneurons and Early Network Activities}

GABergic INs serve diverse functions in developing and in mature networks. As detailed above, they provide local circuit inhibition and participate in the genesis and organisation of specific mature neocortical and limbic oscillations, which in turn modify how local circuits respond to incoming signals. In addition, GABAergic interneurons are critical for the proper maturation and wiring of developing networks $[8,272]$, as well as for the regulation of critical period experience-dependent cortical plasticity [132, 273-276]. In particular, they have been involved in the generation of some of the early postnatal cortical and limbic oscillatory activities appearing during the first postnatal week in rodents. These synchronised network activities are thought to be important for the proper morphological maturation of excitatory and inhibitory neurons, including for the development of complex dendritic trees and synaptic contacts.

The first postnatal activities recorded are the synchronous plateau assemblies (SPAs), which are prolonged gap-junction-mediated calcium plateaus appearing between P0-P3 in the rat hippocampus [277] and neocortex [278]. The cellular substrates that drive these SPAs are still unknown, but it is interesting to note that some subsets of cortical interneurons are extensively interconnected through gap junctions $[69,70,101]$ and could contribute to the generation of SPAs. In the cortex, SPAs progressively coexist with cortical early network oscillations (cENOs) between $\mathrm{P} 0-\mathrm{P} 5$. cENOs are infrequent $(0.01 \mathrm{~Hz})$ synaptically driven calcium events with slow kinetics that depend on glutamatergic AMPA- and NMDA-mediated synaptic activity and that cause sustained depolarisation of large groups of neurons.

These early network activities are then replaced by the giant depolarising potentials (GDPs) recorded in the hippocampus [279] and neocortex [278] between P6-P8. GDPs are much more frequent (mean $0.1 \mathrm{~Hz}$ ), consist of fast calcium events, and are entirely dependent on GABAergic synaptic activity (as they are blocked by the $\mathrm{GABA}_{\mathrm{A}}$ antagonist bicuculline). In the hippocampus, GDPs have been shown to result from the spontaneous activity of a subset of highly connected GABAergic neurons, the hub neurons, that pace whole populations of pyramidal cells in a rhythmic fashion [280]. These hub cells receive more excitatory inputs (EPSPs), display a lower action potential threshold, and have a wider axonal arborisation than neighbouring local GABAergic interneurons [280]. These characteristics render them particularly well suited to generate waves of activity in wide sets of neurons upon stimulation by incoming inputs. GDPs coincide with a phase of active synaptogenesis within the developing neocortical and limbic circuits. It is therefore likely that a selective dysfunction of GABAergic interneurons in these early developmental steps might alter the process of synapse formation, either by decreasing these early network activities or by exerting more direct effects on the postsynaptic membrane.

In summary, interneurons participate in the genesis of early network activities which provide critical input for the normal maturation and plasticity of corticolimbic networks. In the mature brain, they provide local circuit inhibition and govern the onset and maintenance of some of the corticolimbic oscillations. These combined functions underlie the extensive impact of interneuronopathies on neurodevelopment and cognition. 


\section{Interneuronopathies and Neurodevelopmental Disorders}

Interneuron anomalies have been suspected to underlie a variety of neurodevelopmental disorders in humans, including epilepsy, autism, and schizophrenia [14, 15]. This hypothesis stemmed from the observation of decreased GAD67 expression in postmortem brain tissue from affected individuals [110]. Later genetic studies also supported this hypothesis as variants in the GAD67 promoter area were discovered in patients with childhood-onset schizophrenia [113] or bipolar disorder [281]. Interestingly, many other genes linked to neuropsychiatric disease have since been shown to be preferentially expressed in developing cortical interneurons in mice [282]. It is therefore appealing to consider the possibility that genetic anomalies known to affect the development or function of interneurons in mice might be involved in neuropathologies in humans. Although genetic anomalies may manifest differently in mice and humans due to differences in expression patterns or compensation by other genes across species, alterations in highly conserved genetic pathways or disturbances in fundamental physiological processes might translate similarly in humans and mice. Furthermore, a host of environmental factors will likely modify the disease expression in these highly heterogeneous and likely polygenic pathologies. An exhaustive review of the genetic causes of schizophrenia, autism, and epilepsy is beyond the scope of this paper, but we will attempt to summarize some of the compelling evidence pointing to the roles of GABAergic neurons in these disorders.

5.1. Interneuron Development in Humans. Human GABAergic interneurons appear to be highly diverse as initially recognized by Ramon y Cajal [283, 284], with a similar array of PV-positive basket cells, PV-positive chandelier cells, SST-positive Martinotti cells, VIP-CR bitufted cells, VIP bipolar cells, and neurogliaform cells as that described in other species [284, 285]. However, the relative proportion of these various populations varies across species [286]. The superficial cortical layers II-III are considerably larger in the human cortex, presumably underlying some of the enhanced intercortical connectivity mediating higher brain functions in primates. Consequently, CR-positive double-bouquet INs appear to be considerably more numerous in the human cortex [284, 285]. Furthermore, although most cortical GABAergic interneurons develop in the ventral ganglionic eminences in humans, a proportion of cortical INs appear to originate from the cortical ventricular zone [284, 287289]. Nonetheless, similarities do exist with regards to the molecular pathways involved in cortical interneuron genesis in humans and rodents, with preservation of some of the same fundamental genes including Mash1, Dlx1/2, Nkx2-1, and Lhx6 [288, 290-293].

5.2. Interneurons and Schizophrenia. Schizophrenia is a chronic psychiatric condition that combines neurocognitive dysfunctions (i.e., delusions, hallucinations, and disorganisation of thought), negative symptoms (i.e., flat affect, avolition, and alogia), and social or occupational deterioration (i.e., altered social interactions, deterioration in personal hygiene, and inability to self-sustain) [294]. This is accompanied by more specific cognitive impairments such as abnormalities in perception, inferential thinking, volition, linguistic fluency, attention, executive functions (planning), and working memory $[295,296]$.

The involvement of interneurons in the pathophysiology of schizophrenia was suggested when the number of prefrontal cortical GAD67-expressing cells was found to be decreased in autopsy specimens from schizophrenic patients $[109,110]$. There is no net loss of cortical PVpositive interneurons or calretinin-positive interneurons in schizophrenic cortices, as the total number of cells stained for either marker is preserved $[111,112]$. However, there appears to be a selective downregulation of GAD67 in PV-positive interneurons in schizophrenic brains [112]. Furthermore, the level of parvalbumin expression in these cells is decreased [112]. As both parvalbumin and GAD67 expression are known to be regulated by cortical activity [297, 298], these findings could reflect secondary changes in response to altered levels of cortical activity in schizophrenic patients. Indeed, two schizophrenia susceptibility genes encoding the trophic factor neuregulin 1 (NRG1) and its receptor ErbB4 (ERB4) [117-121] have been shown to facilitate activitydependent GABA release from PV-positive basket cells in the mouse prefrontal cortex [299]. Selective loss of ErbB4 in PV cells causes a disinhibition of prefrontal pyramidal cells and results in a schizophrenia-like phenotype in mice [126]. In addition, the specific expression of ErbB4 in PV cells is required for neuregulin-1-dependent regulation of hippocampal long-term potentiation [127], which is altered in schizophrenic patients. Interestingly, hypostimulation of PV-positive basket cells via selective ablation of the NR1 subunit of the NMDA receptors in these cells resulted in schizophrenia-like behaviors (working memory deficits, impaired prepulse inhibition, locomotor hyperactivity, and anxiety) and decreased PV and GAD67 expression in PV basket cells in a mouse model of schizophrenia [128]. Therefore, hypofunction of prefrontal PV INs, either through a primary dysfunction of these cells or a decreased excitatory drive to these cells, appears to result in behavioural consequences in mice, which recapitulate aspects of the phenotype observed in schizophrenic patients.

Additionally, other genetic anomalies found in schizophrenic patients that are predicted to affect cortical maturation more broadly appear to impact interneuron maturation and GAD67 expression. For instance, brain-derived neurotrophic factor (BDNF) is normally released in an activitydependent fashion from pyramidal cells and was shown to regulate the maturation of GABAergic INs [129]. Both BDNF and its receptor $\operatorname{TrkB}$ have been found to be downregulated in the prefrontal cortex of schizophrenic patients [122124]. Knock-out mice for both BDNF and TrkB display behavioral anomalies and a decrease in the synaptic expression of GAD67/GABA [130, 131]. Similarly, the neural cell adhesion molecule NCAM, important for neuronal morphological maturation and synapse formation, requires the addition of a polysialic acid (PSA) moiety to function 
properly. The activity-mediated expression of PSA has been shown to regulate PV-positive basket cell maturation and determine critical-period plasticity [132]. Interestingly, this PSA-NCAM coupling has been reported to be decreased in hippocampal specimens from schizophrenic patients [125], which would suggest abnormalities in interneuron maturation and cortical plasticity.

Another interesting hypothesis is that PV-positive chandelier cells might be affected in schizophrenic brains. Indeed, a specific loss of more than $40 \%$ of the axonal cartridges (the GAT-1 positive axonal branches from chandelier cells which contact the axon initial segments of pyramidal cells) has been demonstrated in the prefrontal cortex of schizophrenic patients $[114,115]$. This is accompanied by enhanced expression of the alpha2 $\mathrm{GABA}_{\mathrm{A}}$ receptor subunit on the axon initial segment of pyramidal cells, likely as a compensatory mechanism for the decreased input from chandelier cells [300]. However, since chandelier cells are possibly excitatory $[94,95]$, the net effect of these structural changes on local cortical excitability is uncertain. More recently, the levels of SST, NPY, and CCK were shown to be decreased in a microarray analysis of prefrontal cortical samples from schizophrenic patients [116] (Table 1). Furthermore, there seems to be a specific decrease in SST-positive interneurons, as shown by in situ hybridisation staining, in these samples [116]. However, these results await replication.

Nonetheless, even if the numbers of various interneuron subtypes are preserved and if the morphological structure of these cells is intact in most cases, functional abnormalities in the connectivity of GABAergic circuits likely play a role in the pathogenesis of psychiatric disorders. Modifications of the specific $\mathrm{GABA}_{\mathrm{A}}$ receptor subunits expressed in the prefrontal cortex of schizophrenic patients have been described [116, 301]. Furthermore, cortical prefrontal gamma oscillations triggered by working memory tasks and selective attention in humans and primates [79-81] are decreased in schizophrenic patients with working memory deficits. These patients display a loss of gamma oscillation power and gamma oscillations are less tightly phase-locked to the task [82, 84, 85]. These changes might reflect functional alterations in the PV-positive basket cells, which contribute to the generation and regulation of the gamma oscillations that synchronise assemblies of pyramidal cells involved in a specific task $[69,72,76-78,83,302]$. In summary, multiple studies point to putative anomalies, either structural or functional, in PV-positive INs in the prefrontal cortex of schizophrenic patients.

5.3. Interneurons and Autism. Autism is a neurodevelopmental disorder combining impairments in socialization, communication, and restricted interests and/or stereotyped behaviors [294]. Autistic traits can be found in a variety of well-defined neurogenetic syndromes, including tuberous sclerosis [303, 304], fragile $\mathrm{X}$ syndrome [133, 134], and Rett syndrome [294]. In addition, nonsyndromic autism (re: without a clear underlying pathology, dysmorphic traits, or structural brain anomalies) has been associated with a variety of de novo copy number variants (CNVs) in large genome-wide association studies [141, 305-308], a finding which must be interpreted with caution [309]. However, the discovery of point mutations in genes encoding various synaptic scaffolding proteins in patients with nonsyndromic autism has begun to shed light on the pathophysiology of this disorder (recently reviewed in [309]). In particular, the discovery of mutations in postsynaptic neuroligins (NRL4X, NRL3) $[135,136]$, in other postsynaptic scaffolding proteins (SHANK2, SHANK3) [137-140, 310], in the presynaptic neurexins $(N R X N 1)[141,142]$, and in fragile $\mathrm{X}$ mental retardation protein (FMR1 gene) suggest that dysfunction in the maintenance of excitatory synapses, synaptic plasticity, and long-term depression participate in the neurobiology of autism and that this might be rescued by metabotropic glutamatergic antagonists [151-154, 156, 311, 312].

In parallel, a dysfunction in GABAergic signalling has been postulated to contribute to the emergence of autistic behaviours. In fact, epilepsy is a frequent comorbidity of autism. Interictal epileptic activity is recorded on scalp EEG in up to $85 \%$ of autistic children, although seizures occur in only $\sim 30 \%$ of patients $[313,314]$ (Table 2 ). This, together with the finding of decreased cortical GAD67/GAD65 expression in autistic patients' brains [143], has suggested that inhibitory dysfunction might play a role in subsets of autistic patients. Furthermore, polymorphisms in the Dlx1/2 genes have been associated with an increased susceptibility for autism [144] supporting the link between GABAergic anomalies and autism. In addition, nonsyndromic autism has been repeatedly associated with maternal chromosomal duplications in the $15 q 11-13$ region $[145,146]$, which includes multiple genes encoding various $\mathrm{GABA}_{\mathrm{A}}$ receptor subunits (GABRA5, GABRG3, and GABRB3). Interestingly, $\mathrm{MecP} 2$, a transcription factor that broadly regulates gene expression by binding methylated CPG islands and which is responsible for the majority of cases of Rett syndrome (see next section), also exerts epigenetic control over this chromosomal region [157]. The loss of MecP2 results in dysregulation of multiple genes, including the downregulation of GABRB3. Furthermore, the loss of $\mathrm{MecP} 2$ is particularly detrimental to interneurons and a conditional MecP2 ablation in GABAergic neurons in mice was recently shown to recapitulate most of the behavioral anomalies associated with Rett syndrome, including autistic-like behavior [158].

Finally, another well-characterised mouse model of autism, the $u P A R^{-/-}$mouse, displays a spatially selective defect in interneuron migration, such that the frontoparietal cortices of these mice show 50\% less calbindin-positive interneurons (with a near absence of PV cells) whereas more caudal cortices are spared $[11,12]$. These mice display autistic-like behaviors with increased anxiety and altered socialisation, as well as interictal epileptiform EEG activity and an increased susceptibility to seizures [11, 12]. $U P A R$ encodes an urokinase plasminogen activator which is required for the proper processing of the hepatocyte growth factor (HGF). In turn, HGF, through its receptor MET, has been shown to be a critical motogen for interneuron migration and is able to rescue the interneuron migration defect and seizure susceptibility of $u P A R^{-/-}$mice $[159,160]$. Interestingly, polymorphisms in the MET promoter have 
TABLE 1: Findings in schizophrenic patients and correlations in mice models.

\begin{tabular}{|c|c|c|}
\hline \multicolumn{2}{|l|}{ Findings } & \multirow[t]{2}{*}{ References } \\
\hline & Humans & \\
\hline \multirow{6}{*}{ GAD67 } & \multirow{2}{*}{$\downarrow$ GAD67 in prefrontal cortex } & Volk et al. [109] \\
\hline & & Akbarian et al. [110] \\
\hline & \multirow{2}{*}{ Preserved \# number of PV cells, cortex } & Woo et al. [111] \\
\hline & & Hashimoto et al. [112] \\
\hline & $\downarrow$ GAD67 level in PV cells, cortex & Hashimoto et al. [112] \\
\hline & Association with polymorphisms in GAD67 promoter & Addington et al. [113] \\
\hline \multirow{2}{*}{ Chandelier } & \multirow{2}{*}{ Decrease in chandelier cells cartridges (GAT1+) in prefrontal cortex } & Woo et al. [114] \\
\hline & & Volk et al. [115] \\
\hline SST & $\downarrow$ levels of SST in microarray analysis and $\downarrow$ number of SST cells, prefrontal cortex & Hashimoto et al. [116] \\
\hline NPY/CCK & $\downarrow$ levels of NPY and CCK in microarray analysis & Hashimoto et al. [116] \\
\hline \multirow{3}{*}{$N R G 1$} & \multirow{3}{*}{ Susceptibility locus in NRG1 } & $\begin{array}{l}\text { Stefansson et al. } \\
{[117,118]}\end{array}$ \\
\hline & & Zhang et al. [119] \\
\hline & & Yang et al. [120] \\
\hline ERB4 & Susceptibility locus in ERB4 & Silberberg et al. [121] \\
\hline \multirow{3}{*}{$\mathrm{BDNF} / \mathrm{Trkb}$} & \multirow{2}{*}{ Downregulation of BDNF in prefrontal cortex } & Weickert et al. [122] \\
\hline & & Wong et al. [123] \\
\hline & Downregulation of BDNF and Trkb in prefrontal cortex & Takahashi et al. [124] \\
\hline PSA/NCAM & $\downarrow$ PSA-NCAM complexes in hippocampus & Barbeau et al. [125] \\
\hline \multirow{4}{*}{ Gamma } & \multirow{2}{*}{ Gamma oscillations are triggered by working memory tasks + selective attention } & Tallon-Baudry et al. [79] \\
\hline & & Howard et al. [81] \\
\hline & \multirow{2}{*}{ Decreased power of cortical gamma oscillations and phase locking to memory task } & Spencer et al. $[82,84]$ \\
\hline & & Cho et al. [85] \\
\hline \multicolumn{3}{|c|}{ Mice } \\
\hline Erb4 & Selective interneuron loss of Erb4: "schizophrenia-like behaviors" & Wen et al. [126] \\
\hline Erb4/Nrg1 & Erb4 in PV cells is required for Nrg1-dependant regulation of LTP (hippocampus) & Chen et al. [127] \\
\hline NR1 & $\begin{array}{l}\text { Selective loss of the NMDAr NR } 1 \text { subunit in PV cells: decreased excitatory input to } \\
\text { PV cells results in "schizophrenia-like behaviors" and } \downarrow \text { expression of PV and } \\
\text { GAD67 }\end{array}$ & Belforte et al. [128] \\
\hline \multirow{3}{*}{$B D N F$} & \multirow{3}{*}{$\begin{array}{l}\text { BDNF regulates activity-dependant maturation of PV cells } \\
\text { Bdnf- }^{-/-} \text {and } \operatorname{Trkb}^{-/-}: \downarrow \text { synaptic GAD } 67 \text { and GABA and behavioral anomalies }\end{array}$} & Huang et al. [129] \\
\hline & & Cotrufo et al. [130] \\
\hline & & Hashimoto et al. [131] \\
\hline PSA/NCAM & $\begin{array}{l}\text { Activity-mediated expression of PSA regulates PV cells maturation and visual } \\
\text { plasticity }\end{array}$ & Di Cristo et al. [132] \\
\hline \multirow{3}{*}{ Gamma } & \multirow{2}{*}{ Gamma oscillations are triggered by stimulating PV cells: enhanced performance } & Cardin et al. [77] \\
\hline & & Sohal et al. [83] \\
\hline & Gamma oscillations depend on PV cells-mediated fast-synaptic inhibition & Bartos et al. [72] \\
\hline
\end{tabular}

recently been described to confer an increased susceptibility to autism and this gene is included in one of the genomic sequences linked to autism susceptibility (7q31) $[149,150]$. Autism is a complex disorder and alterations in other GABAergic circuits, including the striatocortical circuits, likely contribute to this behavioural phenotype. Indeed, an interneuron-selective ablation of MET results in decreased cortical PV cells, but massively increased dorsal striatal PV interneurons, leading to a disruption in striatal-mediated procedural and reversal learning [161]. Nonetheless, cortical and hippocampal GABAergic deficits certainly play a role in some of the cognitive-behavioral manifestations of autism, as well as in the associated susceptibility to seizures.

5.4. Interneurons and Epilepsy. Perhaps one of the most intuitive consequences of interneuron dysfunction is the development of epilepsy. Multiple mouse models carrying interneuronopathies have been shown to develop seizures $[22,28,57,63,206,207,221]$. In parallel, various reports point to probable GABAergic interneuron dysfunction in 
TABLE 2: Findings in autistic children and correlations in mice models.

\begin{tabular}{|c|c|c|}
\hline \multicolumn{2}{|l|}{ Findings } & \multirow[t]{2}{*}{ References } \\
\hline & Humans & \\
\hline \multirow{2}{*}{ FMR1 } & \multirow{2}{*}{ Patients with fragile $\mathrm{X}$ syndrome often display autistic traits } & Levitas et al. [133] \\
\hline & & Brown et al. [134] \\
\hline \multirow{2}{*}{ NRL4X/NRL3 } & Point mutations in NRL4X and NRL3 associated with X-linked autism & Jamain et al. [135] \\
\hline & Point mutations in NRL4X in nonsyndromic autism & $\begin{array}{l}\text { Laumonnier et al. } \\
{[136]}\end{array}$ \\
\hline \multirow{3}{*}{ SHANK3 } & \multirow{3}{*}{ Mutations in SHANK3 in nonsyndromic autism } & Durand et al. [137] \\
\hline & & Gauthier et al. [138] \\
\hline & & Moessner et al. [139] \\
\hline SHANK2 & Mutations in SHANK2 in nonsyndromic autism & Berkel et al. [140] \\
\hline \multirow{2}{*}{ NRXN1 } & \multirow{2}{*}{ Mutations in NRXN1 nonsyndromic autism } & Szatmari et al. [141] \\
\hline & & Kim et al. [142] \\
\hline GAD65/67 & $\downarrow$ levels of GAD65/67 in cortex & Fatemi et al. [143] \\
\hline$D l x 1 / 2$ & Polymorphisms in $D l x 1 / 2$ with increased susceptibility to autism & Liu et al. [144] \\
\hline \multirow{2}{*}{$15 q 11-13$} & Maternal duplications in 15q11-13 in nonsyndromic autism & Baker et al. [145] \\
\hline & including $G A B R A 5, G A B R G 3, G A B R B 3\left(\mathrm{GABA}_{\mathrm{A}} \mathrm{R}\right.$ subunits) & Hogart et al. [146] \\
\hline \multirow{2}{*}{ MECP2 } & Mutations in MECP2 explain the majority of Rett syndrome. & Amir et al. [147] \\
\hline & Patients display autistic behaviors. & Buyse et al. [148] \\
\hline \multirow{2}{*}{ MET } & Polymorphisms in MET promoter associated with autism & Jackson et al. [149] \\
\hline & Susceptibility locus for autism at 7q31 includes MET gene. & Campbell et al. [150] \\
\hline \multicolumn{3}{|c|}{ Mice } \\
\hline \multirow{2}{*}{ Fmr1 } & \multirow{2}{*}{ Fmr1 k/o: behavioral anomalies improve with glutamatergic antagonists } & Dolen et al. [151] \\
\hline & & Bear et al. $[152,153]$ \\
\hline \multirow{3}{*}{$\begin{array}{l}\text { Neuroligins/ } \\
\text { neurexins }\end{array}$} & $\begin{array}{l}\text { NRL1/2 expression in nonneuronal cells trigger synapse formation in presynaptic } \\
\text { cells }\end{array}$ & Scheiffele et al. [154] \\
\hline & $\begin{array}{l}\text { NL-1 overexpression in hippocampal neurons promotes assembly of excitatory and } \\
\text { inhibitory synapses and knock-down results in loss of inhibitory > excitatory } \\
\text { synapses }\end{array}$ & Chih [155] \\
\hline & $\begin{array}{l}\text { Presynaptic } \beta \text {-neurexin induces GABA and glutamate synapse differentiation in } \\
\text { postcell }\end{array}$ & Graf et al. [156] \\
\hline \multirow{4}{*}{ MecP2 } & NRL1,3,4 localise at glutamatergic synapses, NRL2 at both excitatory and inhibitory & Graf et al. [156] \\
\hline & Binds methylated CPG islands and exerts epigenetic control of $U B E 3 A$ and $G A B R 3$ & Samaco et al. [157] \\
\hline & $\begin{array}{l}\text { Interneuron selective loss of } \mathrm{MecP} 2 \text { recapitulates the Rett-like behavioral aN in } \\
\text { mice }\end{array}$ & Chao et al. [158] \\
\hline & $u P A R^{-/-}$displays $50 \%$ loss of IN in cortex and seizure susceptibility & Powell et al. [11] \\
\hline \multirow{3}{*}{$\begin{array}{l}\text { uPAR, HGF, } \\
\text { MET }\end{array}$} & $\mathrm{uPAR}$ is required for the processing of HGF (an interneuron motogen), & Powell et al. [159] \\
\hline & HGF, through its receptor MET, can rescue the phenotype of $\mathrm{uPAR}^{-/-}$mice & Bae et al. $[160]$ \\
\hline & $\begin{array}{l}\text { Interneuron selective MET ablation: } \downarrow \text { PV cortex, } \uparrow \text { striatal PV cells, disrupts } \\
\text { reversal learning }\end{array}$ & Martins et al. [161] \\
\hline
\end{tabular}

developmental and symptomatic (posttraumatic or poststatus epilepticus) epileptic disorders in humans [315-318]. In most situations, early developmental interneuron anomalies might contribute to seizure disorders both by altering the normal development of cortical circuits, as detailed above, and by failing to provide the acute inhibition required to control excessive excitation in the mature network. Paradoxically, in a state of chronic excitation, INs have been shown to contribute actively to ictogenesis when GABA becomes depolarizing due to the failure of chloride extrusion from damaged neurons [319, 320]. Therefore, both a primary dysfunction of GABAergic inhibitory transmission and a secondary switch to excitatory GABAergic transmission could contribute to the pathogenesis of epilepsy. Understanding the molecular mechanisms governing interneuron development, maturation, and normal function would therefore be very informative in our quest to comprehend human epileptic disorders.

Epilepsy is a heterogeneous disorder, and most cases are symptomatic of focal or widespread CNS lesions (e.g., malformations, tumors, infections, trauma, strokes, hypoxia, etc.). INs dysfunctions might contribute to seizure disorders 
TABLE 3: Selected examples of genes causing epilepsy in humans and interneuron dysfunctions in mice.

\begin{tabular}{|c|c|c|}
\hline \multicolumn{2}{|l|}{ Findings } & \multirow[t]{2}{*}{ References } \\
\hline & Humans & \\
\hline \multirow{8}{*}{ SCN1A } & \multirow{3}{*}{ SCN1A mutations explain the majority of Dravet syndrome } & Claes et al. [162]; Ohmori et al. [163] \\
\hline & & Sugawara et al. [164]; Orrico et al. [165] \\
\hline & & Escayg and Goldin et al. [166] \\
\hline & \multirow{3}{*}{$\begin{array}{l}\text { SCN1A mutations display phenotypic heterogeneity: GEFS, febrile } \\
\text { seizures, cognitive impairment }\end{array}$} & Escayg et al. $[167,168]$ \\
\hline & & Fujiwara et al. [169]; Osaka et al. [170] \\
\hline & & Zucca et al. [171]; Orrico et al. [165] \\
\hline & Variants in other channels modify the phenotype of SCN1A: SCN8A & Martin et al. [172] \\
\hline & CACNB4 & Ohmori et al. [173] \\
\hline SCN1B & SCN1B mutations cause GEFS & Wallace et al. [174] \\
\hline$A R X$ & $\begin{array}{l}\text { ARX mutations cause various phenotypes including infantile } \\
\text { spasms }\end{array}$ & Shoubridge et al. [175] \\
\hline \multirow{4}{*}{ CDKL5 } & \multirow{4}{*}{ CDKL5 mutations cause early epileptic encephalopathies } & $\begin{array}{l}\text { Kalscheuer et al. [176]; Weaving et al. } 2004 \\
\text { [177] }\end{array}$ \\
\hline & & Scala et al. [178]; Archer et al. [179] \\
\hline & & Cordova-Fletes et al. [180]; Mei et al. [181] \\
\hline & & Melani et al. [182] \\
\hline MECP2 & $\begin{array}{l}\text { MECP2 mutations explain most cases of Rett syndrome. These } \\
\text { patients often display seizures. }\end{array}$ & Amir et al. [147]; Buyse et al. [148] \\
\hline \multirow[t]{2}{*}{ GABRG2 } & $\begin{array}{l}\text { Mutations in the gamma2 subunit of the } \mathrm{GABA}_{\mathrm{A}} \mathrm{R} \text { cause childhood } \\
\text { absence epilepsy } \pm \text { febrile seizure }\end{array}$ & Wallace et al. [174]; Kananura et al. [183] \\
\hline & $\begin{array}{l}\text { Truncation of } G A B R G 2 \text { causes generalised epilepsy with febrile } \\
\text { seizure (GEFS) }\end{array}$ & Harkin et al. [184] \\
\hline \multirow[t]{2}{*}{ GABRA1 } & $\begin{array}{l}\text { Mutations in the alpha1 subunit of the } \mathrm{GABA}_{\mathrm{A}} \mathrm{R} \text { cause juvenile } \\
\text { myoclonic epilepsy }\end{array}$ & Cossette et al. [185] \\
\hline & $\begin{array}{l}\text { Mutations in the alpha1 subunit of the } \mathrm{GABA}_{\mathrm{A}} \mathrm{R} \text { can also cause } \\
\text { childhood absence epilepsy }\end{array}$ & Maljevic et al. [186] \\
\hline \multirow{2}{*}{ CACNA1A } & Polymorphisms associated with generalised epilepsy syndromes & Chioza et al. [187] \\
\hline & Mutations in $C A C N A 1 A$ can cause ataxia with generalized seizures & Jouvenceau et al. [188]; Imbrici et al. [189] \\
\hline CACNB4 & $\begin{array}{l}\text { Mutations in } C A C N B 4 \text { cause episodic ataxia with generalized } \\
\text { seizures }\end{array}$ & Escayg et al. [190] \\
\hline CACNA1H & $\begin{array}{l}\text { Mutations in T-type calcium channel Cav3.2 cause childhood } \\
\text { absence epilepsy }\end{array}$ & Khosravani et al. [191] \\
\hline \multirow{3}{*}{$N k x 2.1$} & $\begin{array}{l}\text { Nkx2.1 haploinsufficiency leads to the "brain-lung-thyroid } \\
\text { syndrome" }\end{array}$ & Carre et al. [192] \\
\hline & $\begin{array}{l}\text { variable phenotype: severe respiratory distress at birth, } \\
\text { mild-moderate hypothyroidism, chorea }\end{array}$ & Guillot et al. [193] \\
\hline & $\begin{array}{l}\text { Some patients present benign hereditary chorea, occasionally with } \\
\text { cognitive impairment and seizures }\end{array}$ & Kleiner-Fisman et al. [194, 195] \\
\hline Dlx5/6 & $\begin{array}{l}\text { Dlx5/6 mutations result in craniofacial and limb anomalies: } \\
\text { ectodermal dysplasia }\end{array}$ & Morasso et al. [196]; Lo Lacono et al. [197] \\
\hline Sox 6 & $\begin{array}{l}1 \text { patient described with heterozygote Sox } 6 \text { mutation: } \\
\text { craniosynostosis and facial dysmorphisms. }\end{array}$ & Tagariello et al. [198] \\
\hline
\end{tabular}


Table 3: Continued.

\begin{tabular}{|c|c|c|}
\hline \multicolumn{2}{|l|}{ Findings } & \multirow[t]{2}{*}{ References } \\
\hline & Mice & \\
\hline & Scn1a (Nav1.1) expressed in most neuronal populations & Yu et al. [199] \\
\hline \multirow[t]{4}{*}{ Scn1a } & $\begin{array}{l}\text { Scn } 1 a^{+/-} \text {and } S c n 1 a^{-/-} \text {mice develop spontaneous seizures and die } \\
\text { prematurely }\end{array}$ & Yu et al. [199] \\
\hline & $\begin{array}{l}\downarrow \text { sodium currents are specific to GABAergic interneurons in } \\
\operatorname{Scn} 1 a^{+/-} \text {and } \operatorname{Scn} 1 a^{-/-}\end{array}$ & Yu et al. [199] \\
\hline & Selective loss of Scn1a in interneurons recapitulates seizure disorder & Martin et al. [200] \\
\hline & Role in neuronal proliferation and migration & Fricourt et al. $[201,202]$ \\
\hline \multirow[t]{4}{*}{ Arx } & Specific requirement of Arx for interneuron migration & $\begin{array}{l}\text { Friocourt and Parnavelas [203]; Poirier et } \\
\text { al. [204] }\end{array}$ \\
\hline & Arx is a downstream target of $D l x 1$ & Colasante et al. [205] \\
\hline & $\begin{array}{l}\text { Arx (GCG) } 10+7 \text { mice display seizures including spasms and } \downarrow \text { no. of } \\
\text { CB and NPY interneurons }\end{array}$ & Price et al. [206] \\
\hline & $\begin{array}{l}\text { Selective loss of Arx in interneurons recapitulates the seizure } \\
\text { disorder }\end{array}$ & Marsh et al. [207] \\
\hline Cdkl5 & $\begin{array}{l}\text { Cdk15 is coexpressed with Mecp2 in cortical neurons and can } \\
\text { phosphorylate Mecp2 }\end{array}$ & Mari et al. [208], Bertani et al. [209] \\
\hline $\mathrm{MecP} 2$ & $\begin{array}{l}\text { Mecp2 broadly represses gene expression by binding methylated } \\
\text { CPG islands }\end{array}$ & Nan et al. $[210,211]$ \\
\hline \multirow{3}{*}{ Cacnala } & Cacna $1 a^{\text {tg/tg }}$ tottering mutant displays ataxia and absence seizures & Noebels et al. [212]; Fletcher et al. [213] \\
\hline & $\begin{array}{l}\text { Gain of thalamic T-type currents cause enhanced rebound bursting } \\
\text { of TC cells in Cacnala } a^{t g / t g}, \text { Cacnal } a^{\ln / l n}\end{array}$ & Zhang et al. [214]; Tsakiridou et al. [215] \\
\hline & $\begin{array}{l}\text { Interneuron selective ablation of Cacna1a leads to multiple types of } \\
\text { generalised seizures incl. absences }\end{array}$ & Rossignol et al. [63] (abstract) \\
\hline \multirow[t]{2}{*}{ Cacnb4 } & $\begin{array}{l}\text { Cacnb4 } 4^{\text {lh/lh }} \text { loss-of-function mutants display spontaneous absence } \\
\text { seizures and ataxia }\end{array}$ & Burgess et al. [216] \\
\hline & $\begin{array}{l}\text { Thalamic tonic } \mathrm{GABA}_{A} \text { currents enhance rebound bursting of TC } \\
\text { cells in Cacnb4 } 4^{\text {hh/h }}\end{array}$ & Cope et al. [217] \\
\hline \multirow{3}{*}{$D l x 1 / 2$} & $\begin{array}{l}D l x 1^{-/-} D l \times 2^{-/-} \text {mice die perinatally and display a failure of IN } \\
\text { migration to cortex and olfactory bulb }\end{array}$ & $\begin{array}{l}\text { Anderson et al. }[23,218] \text {; Bulfone et al. } \\
\text { [219] }\end{array}$ \\
\hline & $\begin{array}{l}D l x 1^{-/-} D l x 2^{+/-} \text {abnormal laminar distribution of IN and simplified } \\
\text { morphology }\end{array}$ & Cobos et al. [220] \\
\hline & $\begin{array}{l}\text { Dlx } x 1^{-/-} \text {morphological defect and postnatal loss of SST }+/ C R+ \\
\text { interneurons: spontaneous seizures }\end{array}$ & Cobos et al. [221] \\
\hline \multirow[t]{3}{*}{$N k \times 2.1$} & $\begin{array}{l}N k \times 2.1^{-/-} \text {die perinatally. Nkx2.1 is required for MGE interneuron } \\
\text { generation. }\end{array}$ & Sussel et al. [222] \\
\hline & $\begin{array}{l}\text { Interneuron specific removal of } N k x 2.1 \text { results in misspecification of } \\
\text { MGE cells into CGE cells, and seizures }\end{array}$ & Butt et al. [22] \\
\hline & Sox $6^{-/-}$dies perinatally of craniofacial anomalies & \\
\hline \multirow[t]{2}{*}{ Sox6 } & $\begin{array}{l}\text { Conditional loss of Sox6 in interneurons results in } \\
\text { misplaced/ectopic and immature basket cells (loss PV) }\end{array}$ & Batista-Brito et al. [28]; Azim et al. [223] \\
\hline & $\begin{array}{l}\text { Conditional loss of Sox6 in interneurons results in a severe epileptic } \\
\text { encephalopathy }\end{array}$ & Batista-Brito et al. [28] \\
\hline
\end{tabular}

following such insults, as suggested by the finding of limbic interneuronal loss after brain trauma or prolonged seizures [321-324]. Hippocampal somatostatin-positive interneurons appear to be particularly sensitive to seizure-induced damage as demonstrated in animal models of drug-induced epilepsy $[13,108,324,325]$, as well as in patients with chronic temporal lobe epilepsy [326]. This might point to a more selective vulnerability of this cell type which could be amendable to neuroprotective therapies. A loss of hippocampal PV cells [327] and alterations in the axonal 
projections of PV-positive chandelier cells have also been reported in patients with chronic epilepsy $[316,325,328$, 329]. Although it is not clear if these changes are the cause or the consequence of repeated seizures [330, 331], they probably contribute to the chronicity of the disease.

5.5. Interneurons in Genetic Developmental Epilepsies. Perhaps most interestingly, GABAergic interneuron dysfunction might contribute to a subset of genetic developmental epilepsies. In those cryptogenic epilepsies where no apparent etiology is found on examination or imaging (re: no dysmorphic traits or neurocutaneous stigma and normal brain CT/MRI), but where patients present clear neurological dysfunction as episodic seizures with or without interictal cognitive impairment, an underlying circuit dysfunction is postulated. These patients with severe developmental epilepsies (i.e., Ohtahara syndrome, West syndrome, LennoxGastaut syndrome, Dravet syndrome, etc.) are rarely amendable to surgical interventions, and only few reports of neuropathological examination of surgical or postmortem specimens are available. In most cases of West syndrome, the neuropathological evaluation reveals either focal cortical malformations or diffuse brain damage [332-335] but it is found to be "normal" in up to $45 \%$ of cases [336]. Nonetheless, functional inhibitory defects with disrupted $\mathrm{GABA}_{\mathrm{A}} \mathrm{R}$ function or immature patterns of $\mathrm{GABA}_{\mathrm{A}} \mathrm{R}$ subunit expression have been demonstrated in some cases of infantile spasms $[318,337]$. Such inhibitory defects might arise as a consequence of genetic mutations that disrupt genes critical for proper interneuron generation or function. For instance, mutations in the alphal subunit of the voltage-gated sodium channel $\mathrm{Na}_{\mathrm{V}} 1.1$ (SCN1A), the aristaless-related homeobox transcription factor $(A R X)$, the cyclin-dependent kinase-like 5 (CDKL5), various $\mathrm{GABA}_{\mathrm{A}}$ receptor subunits and in the alpha 1 subunit of the voltage-dependent P/Q-type $\mathrm{Ca}^{2+}$ channel (CACNA1A) have been described in patients with a variety of epileptic disorders and similar mutations have been shown to impair GABAergic signalling in rodents (Table 3).

5.5.1. SCN1A. Mutations in SCN1A, which encodes the neuronal voltage-gated sodium channel Nav1.1, have been found to underlie a majority (75-85\%) of cases of severe myoclonic epilepsy of infancy (Dravet syndrome) [162-166]. Interestingly, SCN1A mutations have also been found to cause generalised epilepsy with febrile seizures (GEFS) as well as a variety of disorders with neurocognitive impairment and variable seizure susceptibility $[165,167-171]$. This extended phenotypic variability stems both from the nature of the mutations (nonsense mutations cause Dravet syndrome whereas missense mutations tend to cause different phenotypes depending on their location [166, 338-340]) and from the coexistence of genetic modifiers in other genes [172, 173]. Although Nav1.1 channels are found in most neuronal populations in the rodent brain, their loss was found to result in a more selective impairment of interneuronal transmission in mice $[199,200]$. Nav1.1 channels tend to cluster predominantly at the level of the axon initial segment of PV-positive interneurons [341], and their loss results in failure of PV cells to maintain high frequency firing rates
[341]. By contrast, pyramidal cell transmission is relatively well preserved in Nav1.1 mutants, presumably though compensation by other channels. Therefore, dysfunctions of INs might contribute significantly to the onset of epilepsy in Scnla mutants.

5.5.2. $A R X$. In a similar fashion, mutations in the $A R X$ gene are associated with a variety of neurological syndromes that combine epilepsy and various degrees of cognitive disabilities. The spectrum of phenotypes associated with $A R X$ mutations extends from severe X-linked lissencephaly with ambiguous genitalia and severe myoclonic encephalopathies (Ohtahara syndrome, West syndrome), to isolated nonsyndromic mental retardation [175]. The ARX gene is necessary for proper neural proliferation, migration, and differentiation [201-203,342]. In particular, $A R X$ was shown to be essential for proper migration and laminar positioning of interneurons [203, 204], partly because it is a direct downstream target of Dlx1 [205]. Interestingly, $A R X$ knock-in mice carrying trinucleotide repeat insertion mutations recapitulating mutations found in IS cases, display decreased numbers of telencephalic NPY+ and calbindin+ interneurons, and present an epileptic phenotype with early epileptic spasms [206]. Furthermore, a conditional deletion of $A R X$ in GABAergic interneurons leads to a similar loss of interneuron migration and is sufficient to cause a developmental epileptic phenotype including brief spasmlike seizures [207]. This supports the hypothesis that even if $A R X$ mutations might have broader consequences for cortical development, the specific effect on IN migration is fundamental to the development of epilepsy.

5.5.3. CDKL5/MECP2. Other patients with early epileptic encephalopathies have been found to carry mutations in CDKL5 [176-182], a protein kinase highly expressed in developing and mature neurons [343]. Interestingly, CDKL5 can directly bind and phosphorylate MecP2 and is coexpressed with MecP2 in cortical neurons [208, 209]. In turn, MecP2 is a transcription factor that broadly represses gene expression by binding methylated CPG islands [210, $211]$ and is therefore involved in the epigenetic control of gene expression. MECP2 mutations explain a majority of cases of Rett syndrome [147, 148], a neurodevelopmental disorder manifested by progressive microcephaly, developmental regression, stereotypies, and epilepsy. Interestingly, an interneuron selective ablation of $\mathrm{MecP} 2$ recapitulates most of the neurological and behavioral consequences of $\mathrm{MecP} 2$ knock-out mutations in mice [158]. Since MecP2 is a direct downstream target of CDKL5, it is possible that interneuron dysfunction also contributes to the cognitive and epileptic phenotype seen in both CDKL5 and MecP2 mutants.

5.6. Voltage-Gated $\mathrm{Ca}^{2+}$ Channels. Finally, patients with idiopathic generalized epilepsy syndromes (IGE) have been shown to carry mutations in various $\mathrm{GABA}_{A}$ receptor subunits $[174,183-186,344]$, as well as mutations or polymorphisms in multiple subunits of voltage-gated calcium channels, including the CACNA1A, CACNB4, and CACNA1H genes [187-191, 345]. These patients present 
various combinations of myoclonus, generalised tonicclonic "grand-mal" seizures, and absence seizures "petitmal." Mutant mice carrying loss-of-function mutations in Cacna1a or Cacnb4 display similar generalised spike-wave absence seizures and have been instrumental in advancing our understanding of generalised epilepsies [212, 213, 216, 346]. In these models, an enhanced thalamocortical rebound bursting due to a gain in low-voltage activated $\mathrm{Ca}^{2+}$ currents and excessive thalamic $\mathrm{GABA}_{\mathrm{A}}$ signalling have been shown to result in hypersynchronisation of the thalamocortical circuitry and absence seizures [214, 215, 217, 347]. In addition, we recently demonstrated that selective loss of Cacnala from cortical and limbic MGE-derived interneurons in mice is sufficient to create a severe epileptic encephalopathy with multiple types of generalised seizures [63]. We showed that Cacna1a loss resulted in unreliable neurotransmission from PV-positive interneurons. Furthermore, we demonstrated that concurrent loss of Cacnala from both MGE-derived interneurons and cortical pyramidal cells results in a milder epileptic phenotype characterised by absence seizures [63]. These findings suggest that, in some cases, alterations in MGE-derived interneuron function might lead to a variety of generalised seizures and that the severity of the phenotype can be modulated by the involvement of other neuronal populations. Concurrent with these observations, various mouse models with either misspecified or immature MGEderived interneurons have also been shown to develop severe epilepsies. For instance, $N k \times 2-1^{-/-}$and Sox6 $6^{-/-}$null mutants die embryonically or perinatally due to a variety of craniofacial and lung anomalies [222, 348]. However, conditional mutants lacking either $N k \times 2-1$ or Sox6 in an MGE-specific manner develop generalised seizures during the 2 nd or 3 rd postnatal week, leading to early lethality $[22,28]$. In a similar fashion, $D l \times 1^{-/-}$mice also develop spontaneous seizures [221].

One of the limitations in extending some of the experimental findings from genetic models of interneuronopathy to human diseases is that most of the transcription factors important for interneuron development and specification are also involved in specification of other organs (bone, skin, cartilage, lung, and thyroid). Mutations in these genes therefore cause multisystemic disorders in which neurological involvement is often overlooked. For instance, human heterozygote mutations in Nkx2-1 have been described in a variety of clinical disorders affecting the thyroid, the lungs, and the brain, the so-called "brain-lung-thyroid" syndrome [192]. In some cases, truncating mutations result in severe respiratory failure at birth, due to the lack of surfactant proteins, with mild congenital hypothyroidism and neurocognitive anomalies [193]. In other cases, $N k \times 2-1$ mutations have been described in patients with benign hereditary chorea, a movement disorder occasionally accompanied by intellectual impairment and seizures $[194,195]$. In a similar fashion, heterozygous mutations in $D l \times 5 / 6$ genes cause craniofacial and limb anomalies (ectodermal dysplasias) [196, 197]. Sox6 is known to be important for proper cartilage formation [348-350], and one child with craniosynostosis (premature fusion of the cranial sutures) and facial dysmorphisms has been shown to carry a heterozygous mutation in SOX6
[198]. However, even when direct inferences cannot be made between mouse mutants and human patients, the study of these animal models is instrumental in clarifying the role of specific interneuron populations in preventing various types of seizures and is critical to our understanding of epileptogenesis.

\section{Conclusions and Future Perspectives}

In summary, GABAergic INs include diverse neuronal populations which present significant heterogeneity in terms of their biochemical, morphological, and physiological properties. The fate of these INs is governed by tightly regulated genetic cascades. Disruption of these genetic programs, or of genes important for the proper specification, migration, maturation, and/or function of these cells, leads to a variety of cognitive, behavioural, and neurological consequences including autistic behaviors and epilepsy in rodents and humans. For this reason, furthering our understanding of interneuron development across mammalian species might become the cornerstone for the subsequent development of improved diagnostic approaches, and hopefully new therapeutic strategies, for patients with a variety of neurodevelopmental disorders. A fascinating example of this is the development of stem cell transplantation in the treatment of epileptic disorders in rodents [351, 352]. Other such innovative therapeutic approaches will likely emerge as the exquisite complexity of cortical interneurons diversity unravels.

\section{Acknowledgments}

The author is grateful to J. Hjerling-Leffler, J. Close, and S. Rossignol for their enlightening input in reviewing this paper. The author also wishes to thank the Fond de recherche en santé du Québec (FRSQ), the U. de Montréal, and the Centre de recherche de l'Hôpital Ste-Justine for their support.

\section{References}

[1] N. Tamamaki, Y. Yanagawa, R. Tomioka, J. I. Miyazaki, K. Obata, and T. Kaneko, "Green fluorescent protein expression and colocalization with calretinin, parvalbumin, and somatostatin in the GAD67-GFP knock-in mouse," Journal of Comparative Neurology, vol. 467, no. 1, pp. 60-79, 2003.

[2] C. J. McBain and A. Fisahn, "Interneurons unbound," Nature Reviews Neuroscience, vol. 2, no. 1, pp. 11-23, 2001.

[3] F. Pouille and M. Scanziani, "Enforcement of temporal fidelity in pyramidal cells by somatic feed-forward inhibition," Science, vol. 293, no. 5532, pp. 1159-1163, 2001.

[4] M. Wehr and A. M. Zador, "Balanced inhibition underlies tuning and sharpens spike timing in auditory cortex," Nature, vol. 426, no. 6965, pp. 442-446, 2003.

[5] H. Markram, M. Toledo-Rodriguez, Y. Wang, A. Gupta, G. Silberberg, and $\mathrm{C}$. Wu, "Interneurons of the neocortical inhibitory system," Nature Reviews Neuroscience, vol. 5, no. 10, pp. 793-807, 2004. 
[6] P. Somogyi and T. Klausberger, "Defined types of cortical interneurone structure space and spike timing in the hippocampus," Journal of Physiology, vol. 562, no. 1, pp. 9-26, 2005.

[7] T. Klausberger and P. Somogyi, "Neuronal diversity and temporal dynamics: the unity of hippocampal circuit operations," Science, vol. 321, no. 5885, pp. 53-57, 2008.

[8] R. Batista-Brito and G. Fishell, "Chapter 3 the developmental integration of cortical interneurons into a functional network," Current Topics in Developmental Biology, vol. 87, pp. 81-118, 2009.

[9] B. Rudy, G. Fishell, S. Lee, and J. Hjerling-Leffler, "Three groups of interneurons account for nearly $100 \%$ of neocortical GABAergic neurons," Developmental Neurobiology, vol. 71, no. 1, pp. 45-61, 2010.

[10] J. L. Noebels, “The biology of epilepsy genes," Annual Review of Neuroscience, vol. 26, pp. 599-625, 2003.

[11] E. M. Powell, D. B. Campbell, G. D. Stanwood, C. Davis, J. L. Noebels, and P. Levitt, "Genetic disruption of cortical interneuron development causes region- and GABA cell type-specific deficits, epilepsy, and behavioral dysfunction," The Journal of Neuroscience, vol. 23, no. 2, pp. 622-631, 2003.

[12] P. Levitt, K. L. Eagleson, and E. M. Powell, "Regulation of neocortical interneuron development and the implications for neurodevelopmental disorders," Trends in Neurosciences, vol. 27, no. 7, pp. 400-406, 2004.

[13] R. Cossart, C. Bernard, and Y. Ben-Ari, "Multiple facets of GABAergic neurons and synapses: multiple fates of GABA signalling in epilepsies," Trends in Neurosciences, vol. 28, no. 2, pp. 108-115, 2005.

[14] D. A. Lewis, T. Hashimoto, and D. W. Volk, "Cortical inhibitory neurons and schizophrenia," Nature Reviews Neuroscience, vol. 6, no. 4, pp. 312-324, 2005.

[15] S. Akbarian and H. S. Huang, "Molecular and cellular mechanisms of altered GAD1/GAD67 expression in schizophrenia and related disorders," Brain Research Reviews, vol. 52, no. 2, pp. 293-304, 2006.

[16] J. DeFelipe, "Neocortical neuronal diversity: chemical heterogeneity revealed by colocalization studies of classic neurotransmitters, neuropeptides, calcium-binding proteins, and cell surface molecules," Cerebral Cortex, vol. 3, no. 4, pp. 273289, 1993.

[17] Y. Kawaguchi and Y. Kubota, "Physiological and morphological identification of somatostatin- or vasoactive intestinal polypeptide-containing cells among GABAergic cell subtypes in rat frontal cortex," The Journal of Neuroscience, vol. 16, no. 8, pp. 2701-2715, 1996.

[18] B. Cauli, E. Audinat, B. Lambolez et al., "Molecular and physiological diversity of cortical nonpyramidal cells," The Journal of Neuroscience, vol. 17, no. 10, pp. 3894-3906, 1997.

[19] Y. Kawaguchi and Y. Kubota, "GABAergic cell subtypes and their synaptic connections in rat frontal cortex," Cerebral Cortex, vol. 7, no. 6, pp. 476-486, 1997.

[20] A. Gupta, Y. Wang, and H. Markram, "Organizing principles for a diversity of GABAergic interneurons and synapses in the neocortex," Science, vol. 287, no. 5451, pp. 273-278, 2000.

[21] G. A. Ascoli, L. Alonso-Nanclares, S. A. Anderson et al., "Petilla terminology: nomenclature of features of GABAergic interneurons of the cerebral cortex," Nature Reviews Neuroscience, vol. 9, no. 7, pp. 557-568, 2008.

[22] S. J. B. Butt, V. H. Sousa, M. V. Fuccillo et al., "The requirement of $N k \times 2-1$ in the temporal specification of cortical interneuron subtypes," Neuron, vol. 59, no. 5, pp. 722-732, 2008.
[23] S. A. Anderson, M. Qiu, A. Bulfone et al., "Mutations of the homeobox genes Dlx-1 and Dlx-2 disrupt the striatal subventricular zone and differentiation of late born striatal neurons," Neuron, vol. 19, no. 1, pp. 27-37, 1997.

[24] O. Marín, S. A. Anderson, and J. L. R. Rubenstein, "Origin and molecular specification of striatal interneurons," The Journal of Neuroscience, vol. 20, no. 16, pp. 6063-6076, 2000.

[25] Q. Xu, I. Cobos, E. D. de La Cruz, J. L. Rubenstein, and S. A. Anderson, "Origins of cortical interneuron subtypes," The Journal of Neuroscience, vol. 24, no. 11, pp. 2612-2622, 2004.

[26] T. Du, Q. Xu, P. J. Ocbina, and S. A. Anderson, "NKX2.1 specifies cortical interneuron fate by activating Lhx6," Development, vol. 135, no. 8, pp. 1559-1567, 2008.

[27] Q. Xu, M. Tam, and S. A. Anderson, "Fate mapping Nkx2.1-lineage cells in the mouse telencephalon," Journal of Comparative Neurology, vol. 506, no. 1, pp. 16-29, 2008.

[28] R. Batista-Brito, E. Rossignol, J. Hjerling-Leffler et al., "The cell-intrinsic requirement of Sox6 for cortical interneuron development," Neuron, vol. 63, no. 4, pp. 466-481, 2009.

[29] J. Welagen and S. Anderson, "Origins of neocortical interneurons in mice," Developmental Neurobiology, vol. 71, no. 1, pp. 10-17, 2011.

[30] J. L. Plotkin, N. Wu, M. F. Chesselet, and M. S. Levine, "Functional and molecular development of striatal fastspiking GABAergic interneurons and their cortical inputs," European Journal of Neuroscience, vol. 22, no. 5, pp. 10971108, 2005.

[31] M. F. Chesselet, J. L. Plotkin, N. Wu, and M. S. Levine, "Development of striatal fast-spiking GABAergic interneurons," Progress in Brain Research, vol. 160, pp. 261-272, 2007.

[32] A. R. Woodruff and P. Sah, "Networks of parvalbuminpositive interneurons in the basolateral amygdala," The Journal of Neuroscience, vol. 27, no. 3, pp. 553-563, 2007.

[33] R. Batista-Brito, J. Close, R. Machold, and G. Fishell, "The distinct temporal origins of olfactory bulb interneuron subtypes," The Journal of Neuroscience, vol. 28, no. 15, pp. 3966-3975, 2008.

[34] E. Likhtik, D. Popa, J. Apergis-Schoute, G. A. Fidacaro, and D. Paré, "Amygdala intercalated neurons are required for expression of fear extinction," Nature, vol. 454, no. 7204, pp. 642-645, 2008.

[35] W. A. Truitt, P. L. Johnson, A. D. Dietrich, S. D. Fitz, and A. Shekhar, "Anxiety-like behavior is modulated by a discrete subpopulation of interneurons in the basolateral amygdala," Neuroscience, vol. 160, no. 2, pp. 284-294, 2009.

[36] S. Ciocchi, C. Herry, F. Grenier et al., "Encoding of conditioned fear in central amygdala inhibitory circuits," Nature, vol. 468, no. 7321, pp. 277-282, 2010.

[37] L. Tricoire, K. A. Pelkey, M. I. Daw et al., "Common origins of hippocampal ivy and nitric oxide synthase expressing neurogliaform cells," The Journal of Neuroscience, vol. 30, no. 6, pp. 2165-2176, 2010.

[38] R. R. Waclaw, L. A. Ehrman, A. Pierani, and K. Campbell, "Developmental origin of the neuronal subtypes that comprise the amygdalar fear circuit in the mouse," The Journal of Neuroscience, vol. 30, no. 20, pp. 6944-6953, 2010.

[39] V. Ghiglieri, C. Sgobio, C. Costa, B. Picconi, and P. Calabresi, "Striatum-hippocampus balance: from physiological behavior to interneuronal pathology," Progress in Neurobiology, vol. 94, no. 2, pp. 102-114, 2011.

[40] J. Spampanato, J. Polepalli, and P. Sah, "Interneurons in the basolateral amygdala," Neuropharmacology, vol. 60, pp. 765773, 2010. 
[41] H. Wichterle, D. H. Turnbull, S. Nery, G. Fishell, and A. Alvarez-Buylla, "In utero fate mapping reveals distinct migratory pathways and fates of neurons born in the mammalian basal forebrain," Development, vol. 128, no. 19, pp. 3759-3771, 2001.

[42] S. A. Anderson, C. E. Kaznowski, C. Horn, J. L. R. Rubenstein, and S. K. McConnell, "Distinct origins of neocortical projection neurons and interneurons in vivo," Cerebral Cortex, vol. 12, no. 7, pp. 702-709, 2002.

[43] S. Nery, G. Fishell, and J. G. Corbin, "The caudal ganglionic eminence is a source of distinct cortical and subcortical cell populations," Nature Neuroscience, vol. 5, no. 12, pp. 12791287, 2002.

[44] S. J. B. Butt, M. Fuccillo, S. Nery et al., "The temporal and spatial origins of cortical interneurons predict their physiological subtype," Neuron, vol. 48, no. 4, pp. 591-604, 2005.

[45] G. Miyoshi, S. J. B. Butt, H. Takebayashi, and G. Fishell, "Physiologically distinct temporal cohorts of cortical interneurons arise from telencephalic Olig2-expressing precursors," The Journal of Neuroscience, vol. 27, no. 29, pp. 7786-7798, 2007.

[46] G. Miyoshi, J. Hjerling-Leffler, T. Karayannis et al., "Genetic fate mapping reveals that the caudal ganglionic eminence produces a large and diverse population of superficial cortical interneurons," The Journal of Neuroscience, vol. 30, no. 5, pp. 1582-1594, 2010.

[47] D. M. Gelman, F. J. Martini, S. Nobrega-Pereira et al., "The embryonic preoptic area is a novel source of cortical GABAergic interneurons," The Journal of Neuroscience, vol. 29, no. 29, pp. 9380-9389, 2009.

[48] S. Lee, J. Hjerling-Leffler, E. Zagha, G. Fishell, and B. Rudy, "The largest group of superficial neocortical GABAergic interneurons expresses ionotropic serotonin receptors," The Journal of Neuroscience, vol. 30, no. 50, pp. 16796-16808, 2010.

[49] I. Férézou, B. Cauli, E. L. Hill, J. Rossier, E. Hamel, and B. Lambolez, "5-HT3 receptors mediate serotonergic fast synaptic excitation of neocortical vasoactive intestinal peptide/cholecystokinin interneurons," The Journal of Neuroscience, vol. 22, no. 17, pp. 7389-7397, 2002.

[50] K. Campbell, M. Olsson, and A. Björklund, "Regional incorporation and site-specific differentiation of striatal precursors transplanted to the embryonic forebrain ventricle," Neuron, vol. 15, no. 6, pp. 1259-1273, 1995.

[51] C. P. Wonders and S. A. Anderson, "The origin and specification of cortical interneurons," Nature Reviews Neuroscience, vol. 7, no. 9, pp. 687-696, 2006.

[52] E. M. Goldberg, B. D. Clark, E. Zagha, M. Nahmani, A. Erisir, and B. Rudy, " $\mathrm{K}^{+}$channels at the axon initial segment dampen near-threshold excitability of neocortical fast-spiking GABAergic interneurons," Neuron, vol. 58, no. 3, pp. 387-400, 2008.

[53] M. Helmstaedter, B. Sakmann, and D. Feldmeyer, "Neuronal correlates of local, lateral, and translaminar inhibition with reference to cortical columns," Cerebral Cortex, vol. 19, no. 4, pp. 926-937, 2009.

[54] J. R. Gibson, M. Belerlein, and B. W. Connors, "Two networks of electrically coupled inhibitory neurons in neocortex," Nature, vol. 402, no. 6757, pp. 75-79, 1999.

[55] A. Erisir, D. Lau, B. Rudy, and C. S. Leonard, "Function of specific $\mathrm{K}^{+}$channels in sustained high-frequency firing of fast-spiking neocortical interneurons," Journal of Neurophysiology, vol. 82, no. 5, pp. 2476-2489, 1999.
[56] B. Rudy, A. Chow, D. Lau et al., "Contributions of Kv3 channels to neuronal excitability," Annals of the New York Academy of Sciences, vol. 868, pp. 304-343, 1999.

[57] D. Lau, E. C. Vega-Saenz de Miera, D. Contreras et al., "Impaired fast-spiking, suppressed cortical inhibition, and increased susceptibility to seizures in mice lacking Kv3.2 $\mathrm{K}^{+}$ channel proteins," The Journal of Neuroscience, vol. 20, no. 24, pp. 9071-9085, 2000.

[58] B. Rudy and C. J. McBain, "Kv3 channels: voltage-gated $\mathrm{K}^{+}$channels designed for high-frequency repetitive firing," Trends in Neurosciences, vol. 24, no. 9, pp. 517-526, 2001.

[59] S. Y. Chang, E. Zagha, E. S. Kwon et al., "Distribution of Kv3.3 potassium channel subunits in distinct neuronal populations of mouse brain," Journal of Comparative Neurology, vol. 502, no. 6, pp. 953-972, 2007.

[60] A. V. Zaitsev, N. V. Povysheva, D. A. Lewis, and L. S. Krimer, "P/Q-type, but not N-type, calcium channels mediate GABA release from fast-spiking interneurons to pyramidal cells in rat prefrontal cortex," Journal of Neurophysiology, vol. 97, no. 5, pp. 3567-3573, 2007.

[61] I. Bucurenciu, A. Kulik, B. Schwaller, M. Frotscher, and P. Jonas, "Nanodomain coupling between $\mathrm{Ca}^{2+}$ channels and $\mathrm{Ca}^{2+}$ sensors promotes fast and efficient transmitter release at a cortical GABAergic synapse," Neuron, vol. 57, no. 4, pp. 536-545, 2008.

[62] I. Kruglikov and B. Rudy, "Perisomatic GABA release and thalamocortical integration onto neocortical excitatory cells are regulated by neuromodulators," Neuron, vol. 58, no. 6, pp. 911-924, 2008.

[63] E. Rossignol, I. Kruglikov, A. M. J. M. van den Maagdenberg, G. Fishell, and B. Rudy, "Defective cortical signaling results in generalised seizures," in Proceedings of the 40th Annual Meeting of Neuroscience, Society for Neuroscience, San Diego, Calif, USA, 2010.

[64] D. J. Pinto, J. C. Brumberg, and D. J. Simons, "Circuit dynamics and coding strategies in rodent somatosensory cortex," Journal of Neurophysiology, vol. 83, no. 3, pp. 11581166, 2000

[65] D. J. Pinto, J. A. Hartings, J. C. Brumberg, and D. J. Simons, "Cortical damping: analysis of thalamocortical response transformations in rodent barrel cortex," Cerebral Cortex, vol. 13, no. 1, pp. 33-44, 2003.

[66] L. Gabernet, S. P. Jadhav, D. E. Feldman, M. Carandini, and M. Scanziani, "Somatosensory integration controlled by dynamic thalamocortical feed-forward inhibition," Neuron, vol. 48, no. 2, pp. 315-327, 2005.

[67] S. J. Cruikshank, T. J. Lewis, and B. W. Connors, "Synaptic basis for intense thalamocortical activation of feedforward inhibitory cells in neocortex," Nature Neuroscience, vol. 10, no. 4, pp. 462-468, 2007.

[68] F. Pouille, A. Marin-Burgin, H. Adesnik, B. V. Atallah, and M. Scanziani, "Input normalization by global feedforward inhibition expands cortical dynamic range," Nature Neuroscience, vol. 12, no. 12, pp. 1577-1585, 2009.

[69] G. Tamas, E. H. Buhl, A. Lorincz, and P. Somogyi, "Proximally targeted G.ABAergic synapses and gap junctions synchronize cortical interneurons," Nature Neuroscience, vol. 3, no. 4, pp. 366-371, 2000.

[70] J. Szabadics, A. Lorincz, and G. Tamas, "Beta and gamma frequency synchronization by dendritic gabaergic synapses and gap junctions in a network of cortical interneurons," The Journal of Neuroscience, vol. 21, no. 15, pp. 5824-5831, 2001. 
[71] M. R. Deans, J. R. Gibson, C. Sellitto, B. W. Connors, and D. L. Paul, "Synchronous activity of inhibitory networks in neocortex requires electrical synapses containing connexin36," Neuron, vol. 31, no. 3, pp. 477-485, 2001.

[72] M. Bartos, I. Vida, M. Frotscher et al., "Fast synaptic inhibition promotes synchronized gamma oscillations in hippocampal interneuron networks," Proceedings of the National Academy of Sciences of the United States of America, vol. 99, no. 20, pp. 13222-13227, 2002.

[73] R. D. Traub, M. O. Cunningham, T. Gloveli et al., "GABAenhanced collective behavior in neuronal axons underlies persistent gamma-frequency oscillations," Proceedings of the National Academy of Sciences of the United States of America, vol. 100, no. 19, pp. 11047-11052, 2003.

[74] R. D. Traub, A. Bibbig, F. E. N. LeBeau, E. H. Buhl, and M. A. Whittington, "Cellular mechanisms of neuronal population oscillations in the hippocampus in vitro," Annual Review of Neuroscience, vol. 27, pp. 247-278, 2004.

[75] R. D. Traub, H. Michelson-Law, A. E. J. Bibbig, E. H. Buhl, and M. A. Whittington, "Gap junctions, fast oscillations and the initiation of seizures," Advances in Experimental Medicine and Biology, vol. 548, pp. 110-122, 2004.

[76] M. Bartos, I. Vida, and P. Jonas, "Synaptic mechanisms of synchronized gamma oscillations in inhibitory interneuron networks," Nature Reviews Neuroscience, vol. 8, no. 1, pp. 4556, 2007.

[77] J. A. Cardin, M. Carlén, K. Meletis et al., "Driving fastspiking cells induces gamma rhythm and controls sensory responses," Nature, vol. 459, no. 7247, pp. 663-667, 2009.

[78] D. L. Buhl, K. D. Harris, S. G. Hormuzdi, H. Monyer, and G. Buzsáki, "Selective impairment of hippocampal gamma oscillations in connexin-36 knock-out mouse in vivo," The Journal of Neuroscience, vol. 23, no. 3, pp. 1013-1018, 2003.

[79] C. Tallon-Baudry, O. Bertrand, F. Peronnet, and J. Pernier, "Induced $\gamma$-band activity during the delay of a visual shortterm memory task in humans," The Journal of Neuroscience, vol. 18, no. 11, pp. 4244-4254, 1998.

[80] P. Fries, J. H. Reynolds, A. E. Rorie, and R. Desimone, "Modulation of oscillatory neuronal synchronization by selective visual attention," Science, vol. 291, no. 5508, pp. 1560-1563, 2001.

[81] M. W. Howard, D. S. Rizzuto, J. B. Caplan et al., "Gamma oscillations correlate with working memory load in humans," Cerebral Cortex, vol. 13, no. 12, pp. 1369-1374, 2003.

[82] K. M. Spencer, P. G. Nestor, M. A. Niznikiewicz, D. F. Salisbury, M. E. Shenton, and R. W. McCarley, "Abnormal neural synchrony in schizophrenia," The Journal of Neuroscience, vol. 23, no. 19, pp. 7407-7411, 2003.

[83] V. S. Sohal, F. Zhang, O. Yizhar, and K. Deisseroth, "Parvalbumin neurons and gamma rhythms enhance cortical circuit performance," Nature, vol. 459, no. 7247, pp. 698-702, 2009.

[84] K. M. Spencer, P. G. Nestor, R. Perlmutter et al., "Neural synchrony indexes disordered perception and cognition in schizophrenia," Proceedings of the National Academy of Sciences of the United States of America, vol. 101, no. 49, pp. 17288-17293, 2004.

[85] R. Y. Cho, R. O. Konecky, and C. S. Carter, "Impairments in frontal cortical $\gamma$ synchrony and cognitive control in schizophrenia," Proceedings of the National Academy of Sciences of the United States of America, vol. 103, no. 52, pp. 19878-19883, 2006.

[86] Y. Kawaguchi, "Physiological subgroups of nonpyramidal cells with specific morphological characteristics in layer II/III of rat frontal cortex," The Journal of Neuroscience, vol. 15, no. 4, pp. 2638-2655, 1995.

[87] G. Gonzalez-Burgos, L. S. Krimer, N. V. Povysheva, G. Barrionuevo, and D. A. Lewis, "Functional properties of fast spiking interneurons and their synaptic connections with pyramidal cells in primate dorsolateral prefrontal cortex," Journal of Neurophysiology, vol. 93, no. 2, pp. 942-953, 2005.

[88] E. G. Jones, "Varieties and distribution of non pyramidal cells in the somatic sensory cortex of the squirrel monkey," Journal of Comparative Neurology, vol. 160, no. 2, pp. 205-267, 1975.

[89] A. Fairen and F. Valverde, "A specialized type of neuron in the visual cortex of cat: golgi golgi and electron microscope study of chandelier cells," Journal of Comparative Neurology, vol. 194, no. 4, pp. 761-779, 1980.

[90] J. DeFelipe, S. H. C. Hendry, and E. G. Jones, "Visualization of chandelier cell axons by parvalbumin immunoreactivity in monkey cerebral cortex," Proceedings of the National Academy of Sciences of the United States of America, vol. 86, no. 6, pp. 2093-2097, 1989.

[91] P. Somogyi, "A specific "axo-axonal" interneuron in the visual cortex of the rat," Brain Research, vol. 136, no. 2, pp. 345-350, 1977.

[92] J. Szabadics, C. Varga, G. Molnar, S. Olah, P. Barzo, and G. Tamas, "Excitatory effect of GABAergic axo-axonic cells in cortical microcircuits," Science, vol. 311, no. 5758, pp. 233235, 2006.

[93] S. Khirug, J. Yamada, R. Afzalov, J. Voipio, L. Khiroug, and K. Kaila, "GABAergic depolarization of the axon initial segment in cortical principal neurons is caused by the $\mathrm{Na}-\mathrm{K}-2 \mathrm{Cl}$ cotransporter NKCC1," The Journal of Neuroscience, vol. 28, no. 18 , pp. 4635-4639, 2008.

[94] A. R. Woodruff, Q. Xu, S. A. Anderson, and R. Yuste, "Depolarizing effect of neocortical chandelier neurons," Frontiers in Neural Circuits, vol. 3, no. 15, 10 pages, 2009.

[95] A. R. Woodruff, S. A. Anderson, R. Yuste et al., "The enigmatic function of chandelier cells," Frontiers in Neuroscience, vol. 4, article 201, 2010.

[96] L. L. Glickfeld, J. D. Roberts, P. Somogyi, and M. Scanziani, "Interneurons hyperpolarize pyramidal cells along their entire somatodendritic axis," Nature Neuroscience, vol. 12, no. 1, pp. 21-23, 2009.

[97] T. Klausberger, P. J. Magill, L. F. Marton et al., "Brain-state and cell-type-specific firing of hippocampal interneurons in vivo," Nature, vol. 421, no. 6925, pp. 844-848, 2003.

[98] B. Halabisky, F. Shen, J. R. Huguenard, and D. A. Prince, "Electrophysiological classification of somatostatin-positive interneurons in mouse sensorimotor cortex," Journal of Neurophysiology, vol. 96, no. 2, pp. 834-845, 2006.

[99] Y. Ma, H. Hu, A. S. Berrebi, P. H. Mathers, and A. Agmon, "Distinct subtypes of somatostatin-containing neocortical interneurons revealed in transgenic mice," The Journal of Neuroscience, vol. 26, no. 19, pp. 5069-5082, 2006.

[100] L. M. McGarry, A. M. Packer, E. Fino, V. Nikolenko, T. Sippy, and R. Yuste, "Quantitative classification of somatostatinpositive neocortical interneurons identifies three interneuron subtypes," Frontiers in Neural Circuits, vol. 4, no. 12, 19 pages, 2010.

[101] E. E. Fanselow, K. A. Richardson, and B. W. Connors, "Selective, state-dependent activation of somatostatin-expressing inhibitory interneurons in mouse neocortex," Journal of Neurophysiology, vol. 100, no. 5, pp. 2640-2652, 2008.

[102] Y. Wang, M. Toledo-Rodriguez, A. Gupta et al., "Anatomical, physiological and molecular properties of Martinotti cells 
in the somatosensory cortex of the juvenile rat," Journal of Physiology, vol. 561, no. 1, pp. 65-90, 2004.

[103] M. Uematsu, Y. Hirai, F. Karube et al., "Quantitative chemical composition of cortical GABAergic neurons revealed in transgenic venus-expressing rats," Cerebral Cortex, vol. 18, no. 2, pp. 315-330, 2008.

[104] M. Murayama, E. Pérez-Garci, T. Nevian, T. Bock, W. Senn, and M. E. Larkum, "Dendritic encoding of sensory stimuli controlled by deep cortical interneurons," Nature, vol. 457, no. 7233, pp. 1137-1141, 2009.

[105] G. Silberberg and H. Markram, "Disynaptic inhibition between neocortical pyramidal cells mediated by martinotti cells," Neuron, vol. 53, no. 5, pp. 735-746, 2007.

[106] T. K. Berger, R. Perin, G. Silberberg, and H. Markram, "Frequency-dependent disynaptic inhibition in the pyramidal network: a ubiquitous pathway in the developing rat neocortex," Journal of Physiology, vol. 587, no. 22, pp. 54115425, 2009.

[107] E. E. Fanselow and B. W. Connors, "The roles of somatostatin-expressing (GIN) and fast-spiking inhibitory interneurons in UP-DOWN states of mouse neocortex," Journal of Neurophysiology, vol. 104, no. 2, pp. 596-606, 2010.

[108] R. Cossart, C. Dinocourt, J. C. Hirsch et al., "Dendritic but not somatic GABAergic inhibition is decreased in experimental epilepsy," Nature Neuroscience, vol. 4, no. 1, pp. 52-62, 2001.

[109] D. W. Volk, M. C. Austin, J. N. Pierri, A. R. Sampson, and D. A. Lewis, "Decreased glutamic acid decarboxylase ${ }_{67}$ messenger RNA expression in a subset of prefrontal cortical $\gamma$ aminobutyric acid neurons in subjects with schizophrenia," Archives of General Psychiatry, vol. 57, no. 3, pp. 237-245, 2000.

[110] S. Akbarian, J. J. Kim, S. G. Potkin et al., "Gene expression for glutamic acid decarboxylase is reduced without loss of neurons in prefrontal cortex of schizophrenics," Archives of General Psychiatry, vol. 52, no. 4, pp. 258-278, 1995.

[111] T. U. Woo, J. L. Miller, and D. A. Lewis, "Schizophrenia and the parvalbumin-containing class of cortical local circuit neurons," American Journal of Psychiatry, vol. 154, no. 7, pp. 1013-1015, 1997.

[112] T. Hashimoto, D. W. Volk, S. M. Eggan et al., "Gene expression deficits in a subclass of GABA neurons in the prefrontal cortex of subjects with schizophrenia," The Journal of Neuroscience, vol. 23, no. 15, pp. 6315-6326, 2003.

[113] A. M. Addington, M. Gornick, J. Duckworth et al., "GAD1 (2q31.1), which encodes glutamic acid decarboxylase $\left(\mathrm{GAD}_{67}\right)$, is associated with childhood-onset schizophrenia and cortical gray matter volume loss," Molecular Psychiatry, vol. 10, no. 6, pp. 581-588, 2005.

[114] T. U. Woo, R. E. Whitehead, D. S. Melchitzky, and D. A. Lewis, "A subclass of prefrontal $\gamma$-aminobutyric acid axon terminals are selectively altered in schizophrenia," Proceedings of the National Academy of Sciences of the United States of America, vol. 95, no. 9, pp. 5341-5346, 1998.

[115] D. W. Volk, M. C. Austin, J. N. Pierri, A. R. Sampson, and D. A. Lewis, "GABA transporter-1 mRNA in the prefrontal cortex in schizophrenia: decreased expression in a subset of neurons," American Journal of Psychiatry, vol. 158, no. 2, pp. 256-265, 2001.

[116] T. Hashimoto, D. Arion, T. Unger et al., "Alterations in GABA-related transcriptome in the dorsolateral prefrontal cortex of subjects with schizophrenia," Molecular Psychiatry, vol. 13, no. 2, pp. 147-161, 2008.
[117] H. Stefansson, E. Sigurdsson, V. Steinthorsdottir et al., "Neuregulin 1 and susceptibility to schizophrenia," American Journal of Human Genetics, vol. 71, no. 4, pp. 877-892, 2002.

[118] H. Stefansson, J. Sarginson, A. Kong et al., "Association of neuregulin 1 with schizophrenia confirmed in a Scottish population," American Journal of Human Genetics, vol. 72, no. 1, pp. 83-87, 2003.

[119] H. X. Zhang, W. Q. Li, Y. Zhang, J. P. Zhao, L. X. Lv, and G. Yang, "Association analysis of neuregulin 1 gene polymorphism with schizophrenia in Chinese Han population," Zhonghua Yi Xue Yi Chuan Xue Za Zhi, vol. 26, no. 1, pp. 16-20, 2009.

[120] J. Z. Yang, T. M. Si, Y. Ruan et al., "Association study of neuregulin 1 gene with schizophrenia," Molecular Psychiatry, vol. 8, no. 7, pp. 706-709, 2003.

[121] G. Silberberg, A. Darvasi, R. Pinkas-Kramarski, and R. Navon, "The involvement of ErbB4 with schizophrenia: association and expression studies," American Journal of Medical Genetics Part B, vol. 141, no. 2, pp. 142-148, 2006.

[122] C. S. Weickert, T. M. Hyde, B. K. Lipska, M. M. Herman, D. R. Weinberger, and J. E. Kleinman, "Reduced brain-derived neurotrophic factor in prefrontal cortex of patients with schizophrenia," Molecular Psychiatry, vol. 8, no. 6, pp. 592610, 2003.

[123] J. Wong, T. M. Hyde, H. L. Cassano, A. Deep-Soboslay, J. E. Kleinman, and C. S. Weickert, "Promoter specific alterations of brain-derived neurotrophic factor mRNA in schizophrenia," Neuroscience, vol. 169, no. 3, pp. 1071-1084, 2010.

[124] M. Takahashi, O. Shirakawa, K. Toyooka et al., "Abnormal expression of brain-derived neurotrophic factor and its receptor in the corticolimbic system of schizophrenic patients," Molecular Psychiatry, vol. 5, no. 3, pp. 293-300, 2000.

[125] D. Barbeau, J. J. Liang, Y. Robitaille, R. Quirion, and L. K. Srivastava, "Decreased expression of the embryonic form of the neural cell adhesion molecule in schizophrenic brains," Proceedings of the National Academy of Sciences of the United States of America, vol. 92, no. 7, pp. 2785-2789, 1995.

[126] L. Wen, Y. S. Lu, X. H. Zhu et al., "Neuregulin 1 regulates pyramidal neuron activity via ErbB4 in parvalbumin-positive interneurons," Proceedings of the National Academy of Sciences of the United States of America, vol. 107, no. 3, pp. 1211-1216, 2010.

[127] Y. J. Chen, M. Zhang, D. M. Yin et al., "ErbB4 in parvalbumin-positive interneurons is critical for neuregulin 1 regulation of long-term potentiation," Proceedings of the National Academy of Sciences of the United States of America, vol. 107, no. 50, pp. 21818-21823, 2010.

[128] J. E. Belforte, V. Zsiros, E. R. Sklar et al., "Postnatal NMDA receptor ablation in corticolimbic interneurons confers schizophrenia-like phenotypes," Nature Neuroscience, vol. 13, no. 1, pp. 76-83, 2010.

[129] Z. J. Huang, A. Kirkwood, T. Pizzorusso et al., "BDNF regulates the maturation of inhibition and the critical period of plasticity in mouse visual cortex," Cell, vol. 98, no. 6, pp. 739-755, 1999.

[130] T. Cotrufo, A. Viegi, N. Berardi, Y. Bozzi, L. Mascia, and L. Maffei, "Effects of neurotrophins on synaptic protein expression in the visual cortex of dark-reared rats," The Journal of Neuroscience, vol. 23, no. 9, pp. 3566-3571, 2003.

[131] T. Hashimoto, S. E. Bergen, Q. L. Nguyen et al., "Relationship of brain-derived neurotrophic factor and its receptor TrkB to 
altered inhibitory prefrontal circuitry in schizophrenia," The Journal of Neuroscience, vol. 25, no. 2, pp. 372-383, 2005.

[132] G. Di Cristo, B. Chattopadhyaya, S. J. Kuhlman et al., "Activity-dependent PSA expression regulates inhibitory maturation and onset of critical period plasticity," Nature Neuroscience, vol. 10, no. 12, pp. 1569-1577, 2007.

[133] A. Levitas, R. J. Hagerman, M. Braden, B. Rimland, P. McBogg, and I. Matus, "Autism and the fragile X syndrome," Journal of Developmental \& Behavioral Pediatrics, vol. 4, no. 3, pp. 151-158, 1983.

[134] W. T. Brown, E. C. Jenkins, I. L. Cohen et al., "Fragile X and autism: a multicenter survey," American Journal of Medical Genetics, vol. 23, no. 1-2, pp. 341-352, 1986.

[135] S. Jamain, H. Quach, C. Betancur et al., "Mutations of the Xlinked genes encoding neuroligins NLGN3 and NLGN4 are associated with autism," Nature Genetics, vol. 34, no. 1, pp. 27-29, 2003.

[136] F. Laumonnier, F. Bonnet-Brilhault, M. Gomot et al., "Xlinked mental retardation and autism are associated with a mutation in the NLGN4 gene, a member of the neuroligin family," American Journal of Human Genetics, vol. 74, no. 3, pp. 552-557, 2004.

[137] C. M. Durand, C. Betancur, T. M. Boeckers et al., "Mutations in the gene encoding the synaptic scaffolding protein SHANK3 are associated with autism spectrum disorders," Nature Genetics, vol. 39, no. 1, pp. 25-27, 2007.

[138] J. Gauthier, D. Spiegelman, A. Piton et al., "Novel de novo SHANK3 mutation in autistic patients," American Journal of Medical Genetics Part B, vol. 150, no. 3, pp. 421-424, 2009.

[139] R. Moessner, C. R. Marshall, J. S. Sutcliffe et al., "Contribution of SHANK3 mutations to autism spectrum disorder," American Journal of Human Genetics, vol. 81, no. 6, pp. 12891297, 2007.

[140] S. Berkel, C. R. Marshall, B. Weiss et al., "Mutations in the SHANK2 synaptic scaffolding gene in autism spectrum disorder and mental retardation," Nature Genetics, vol. 42, no. 6, pp. 489-491, 2010.

[141] P. Szatmari, A. D. Paterson, L. Zwaigenbaum et al., "Mapping autism risk loci using genetic linkage and chromosomal rearrangements," Nature Genetics, vol. 39, no. 3, pp. 319-328, 2007.

[142] H. G. Kim, S. Kishikawa, A. W. Higgins et al., "Disruption of neurexin 1 associated with autism spectrum disorder," American Journal of Human Genetics, vol. 82, no. 1, pp. 199207, 2008.

[143] S. H. Fatemi, A. R. Halt, J. M. Stary, R. Kanodia, S. C. Schulz, and G. R. Realmuto, "Glutamic acid decarboxylase 65 and 67 $\mathrm{kDa}$ proteins are reduced in autistic parietal and cerebellar cortices," Biological Psychiatry, vol. 52, no. 8, pp. 805-810, 2002.

[144] X. Liu, N. Novosedlik, A. Wang et al., "The DLX1and DLX2 genes and susceptibility to autism spectrum disorders," European Journal of Human Genetics, vol. 17, no. 2, pp. 228235, 2009.

[145] P. Baker, J. Piven, S. Schwartz, and S. Patil, "Brief report: duplication of chromosome 15q11-13 in two individuals with autistic disorder," Journal of Autism and Developmental Disorders, vol. 24, no. 4, pp. 529-535, 1994.

[146] A. Hogart, D. Wu, J. M. LaSalle, and N. C. Schanen, "The comorbidity of autism with the genomic disorders of chromosome 15q11.2-q13," Neurobiology of Disease, vol. 38, no. 2, pp. 181-191, 2010.

[147] R. E. Amir, I. B. van den Veyver, M. Wan, C. Q. Tran, U. Francke, and H. Y. Zoghbi, "Rett syndrome is caused by mutations in X-linked MECP2, encoding methyl-CpGbinding protein 2," Nature Genetics, vol. 23, no. 2, pp. 185$188,1999$.

[148] I. M. Buyse, P. Fang, K. T. Hoon, R. E. Amir, H. Y. Zoghbi, and B. B. Roa, "Diagnostic testing for Rett syndrome by DHPLC and direct sequencing analysis of the MECP2 gene: identification of several novel mutations and polymorphisms," American Journal of Human Genetics, vol. 67, no. 6, pp. 14281436, 2000.

[149] P. B. Jackson, L. Boccuto, C. Skinner et al., "Further evidence that the rs1858830 C variant in the promoter region of the MET gene is associated with autistic disorder," Autism Research, vol. 2, no. 4, pp. 232-236, 2009.

[150] D. B. Campbell, J. S. Sutcliffe, P. J. Ebert et al., "A genetic variant that disrupts MET transcription is associated with autism," Proceedings of the National Academy of Sciences of the United States of America, vol. 103, no. 45, pp. 16834-16839, 2006.

[151] G. Dölen, E. Osterweil, B. S. S. Rao et al., "Correction of fragile X syndrome in mice," Neuron, vol. 56, no. 6, pp. 955962, 2007.

[152] M. F. Bear, K. M. Huber, and S. T. Warren, "The mGluR theory of fragile X mental retardation," Trends in Neurosciences, vol. 27, no. 7, pp. 370-377, 2004.

[153] M. F. Bear, G. Dölen, E. Osterweil, and N. Nagarajan, "Fragile X: translation in action," Neuropsychopharmacology, vol. 33, no. 1, pp. 84-87, 2008.

[154] P. Scheiffele, J. Fan, J. Choih, R. Fetter, and T. Serafini, "Neuroligin expressed in nonneuronal cells triggers presynaptic development in contacting axons," Cell, vol. 101, no. 6, pp. 657-669, 2000.

[155] B. Chih, H. Engelman, P. Scheiffele et al., "Control of excitatory and inhibitory synapse formation by neuroligins," Science, vol. 307, no. 5713, pp. 1324-1328, 2005.

[156] E. R. Graf, X. Zhang, S. X. Jin, M. W. Linhoff, and A. M. Craig, "Neurexins induce differentiation of GABA and glutamate postsynaptic specializations via neuroligins," Cell, vol. 119, no. 7, pp. 1013-1026, 2004.

[157] R. C. Samaco, A. Hogart, and J. M. LaSalle, "Epigenetic overlap in autism-spectrum neurodevelopmental disorders: $M E C P 2$ deficiency causes reduced expression of UBE3A and GABRB3," Human Molecular Genetics, vol. 14, no. 4, pp. 483492, 2005.

[158] H. T. Chao, H. Chen, R. C. Samaco et al., "Dysfunction in GABA signalling mediates autism-like stereotypies and Rett syndrome phenotypes," Nature, vol. 468, no. 7321, pp. 263269, 2010.

[159] E. M. Powell, W. M. Mars, and P. Levitt, "Hepatocyte growth factor/scatter factor is a motogen for interneurons migrating from the ventral to dorsal telencephalon," Neuron, vol. 30, no. 1, pp. 79-89, 2001.

[160] M. H. Bae, G. B. Bissonette, W. M. Mars et al., "Hepatocyte growth factor (HGF) modulates GABAergic inhibition and seizure susceptibility," Experimental Neurology, vol. 221, no. 1, pp. 129-135, 2010.

[161] G. J. Martins, M. Shahrokh, and E. M. Powell, "Genetic disruption of Met signaling impairs GABAergic striatal development and cognition," Neuroscience, vol. 176, no. 10, pp. 199-209, 2010.

[162] L. Claes, J. Del-Favero, B. Ceulemans, L. Lagae, C. van Broeckhoven, and P. de Jonghe, "De novo mutations in the sodium-channel gene SCN1A cause severe myoclonic epilepsy of infancy," American Journal of Human Genetics, vol. 68 , no. 6 , pp. 1327-1332, 2001. 
[163] I. Ohmori, M. Ouchida, Y. Ohtsuka, E. Oka, and K. Shimizu, "Significant correlation of the SCN1A mutations and severe myoclonic epilepsy in infancy," Biochemical and Biophysical Research Communications, vol. 295, no. 1, pp. 17-23, 2002.

[164] T. Sugawara, E. Mazaki-Miyazaki, K. Fukushima et al., "Frequent mutations of SCN1A in severe myoclonic epilepsy in infancy," Neurology, vol. 58, no. 7, pp. 1122-1124, 2002.

[165] A. Orrico, L. Galli, S. Grosso et al., "Mutational analysis of the SCN1A, SCN1B and GABRG2 genes in 150 Italian patients with idiopathic childhood epilepsies," Clinical Genetics, vol. 75, no. 6, pp. 579-581, 2009.

[166] A. Escayg and A. L. Goldin, "Sodium channel SCN1A and epilepsy: mutations and mechanisms," Epilepsia, vol. 51, no. 9, pp. 1650-1658, 2010.

[167] A. Escayg, B. T. MacDonald, M. H. Meisler et al., "Mutations of SCN1A, encoding a neuronal sodium channel, in two families with GEFS+2," Nature Genetics, vol. 24, no. 4, pp. 343-345, 2000.

[168] A. Escayg, A. Heils, B. T. Macdonald, K. Haug, T. Sander, and M. H. Meisler, "A novel SCN1A mutation associated with generalized epilepsy with febrile seizures plus-and prevalence of variants in patients with epilepsy," American Journal of Human Genetics, vol. 68, no. 4, pp. 866-873, 2001.

[169] T. Fujiwara, T. Sugawara, E. Mazaki-Miyazaki et al., "Mutations of sodium channel $\alpha$ subunit type 1 (SCN1A) in intractable childhood epilepsies with frequent generalized tonic-clonic seizures," Brain, vol. 126, no. 3, pp. 531-546, 2003.

[170] H. Osaka, I. Ogiwara, E. Mazaki et al., "Patients with a sodium channel alpha 1 gene mutation show wide phenotypic variation," Epilepsy Research, vol. 75, no. 1, pp. 46-51, 2007.

[171] C. Zucca, F. Redaelli, R. Epifanio et al., "Cryptogenic epileptic syndromes related to SCN1A: twelve novel mutations identified," Archives of Neurology, vol. 65, no. 4, pp. 489-494, 2008.

[172] M. S. Martin, B. Tang, L. A. Papale, F. H. Yu, W. A. Catterall, and A. Escayg, "The voltage-gated sodium channel Scn8a is a genetic modifier of severe myoclonic epilepsy of infancy," Human Molecular Genetics, vol. 16, no. 23, pp. 2892-2899, 2007.

[173] I. Ohmori, M. Ouchida, T. Miki et al., "A CACNB4 mutation shows that altered $\mathrm{Ca}_{\mathrm{v}} 2.1$ function may be a genetic modifier of severe myoclonic epilepsy in infancy," Neurobiology of Disease, vol. 32, no. 3, pp. 349-354, 2008.

[174] R. H. Wallace, C. Marini, S. Petrou et al., "Mutant GABA receptor $\gamma 2$-subunit in childhood absence epilepsy and febrile seizures," Nature Genetics, vol. 28, no. 1, pp. 49-52, 2001.

[175] C. Shoubridge, T. Fullston, and J. Gécz, "ARX spectrum disorders: making inroads into the molecular pathology," Human Mutation, vol. 31, no. 8, pp. 889-900, 2010.

[176] V. M. Kalscheuer, J. Tao, A. Donnelly et al., "Disruption of the serine/threonine kinase 9 gene causes severe X-linked infantile spasms and mental retardation," American Journal of Human Genetics, vol. 72, no. 6, pp. 1401-1411, 2003.

[177] L. S. Weaving, J. Christodoulou, S. L. Williamson et al., "Mutations of CDKL5 cause a severe neurodevelopmental disorder with infantile spasms and mental retardation," American Journal of Human Genetics, vol. 75, no. 6, pp. 10791093, 2004.

[178] E. Scala, F. Ariani, F. Mari et al., "CDKL5/STK9 is mutated in Rett syndrome variant with infantile spasms," Journal of Medical Genetics, vol. 42, no. 2, pp. 103-107, 2005.
[179] H. L. Archer, J. Evans, S. Edwards et al., "CDKL5 mutations cause infantile spasms, early onset seizures, and severe mental retardation in female patients," Journal of Medical Genetics, vol. 43, no. 9, pp. 729-734, 2006.

[180] C. Cordova-Fletes, N. Rademacher, I. Muller et al., "CDKL5 truncation due to a $\mathrm{t}(\mathrm{X} ; 2)(\mathrm{p} 22.1 ; \mathrm{p} 25.3)$ in a girl with $\mathrm{X}$ linked infantile spasm syndrome," Clinical Genetics, vol. 77, no. 1, pp. 92-96, 2010.

[181] D. Mei, C. Marini, F. Novara et al., "Xp22.3 genomic deletions involving the CDKL5 gene in girls with early onset epileptic encephalopathy," Epilepsia, vol. 51, no. 4, pp. 647654, 2010.

[182] F. Melani, D. Mei, T. Pisano et al., “CDKL5 gene-related epileptic encephalopathy: electroclinical findings in the first year of life," Developmental Medicine and Child Neurology, vol. 53,, no. 4, pp. 354-360, 2010.

[183] C. Kananura, K. Haug, T. Sander et al., "A splice-site mutation in GABRG2 associated with childhood absence epilepsy and febrile convulsions," Archives of Neurology, vol. 59, no. 7, pp. 1137-1141, 2002.

[184] L. A. Harkin, D. N. Bowser, L. M. Dibbens et al., "Truncation of the $\mathrm{GABA}_{\mathrm{A}}$-receptor $\gamma 2$ subunit in a family with generalized epilepsy with febrile seizures plus," American Journal of Human Genetics, vol. 70, no. 2, pp. 530-536, 2002.

[185] P. Cossette, L. Liu, K. Brisebois et al., "Mutation of GABRA1 in an autosomal dominant form of juvenile myoclonic epilepsy,” Nature Genetics, vol. 31, no. 2, pp. 184-189, 2002.

[186] S. Maljevic, K. Krampfl, J. Cobilanschi et al., "A mutation in the $\mathrm{GABA}_{\mathrm{A}}$ receptor $\alpha_{1}$-subunit is associated with absence epilepsy," Annals of Neurology, vol. 59, pp. 983-987, 2006.

[187] B. Chioza, H. Wilkie, L. Nashef et al., "Association between the $\alpha 1$ a calcium channel gene CACNA1A and idiopathic generalized epilepsy," Neurology, vol. 56, no. 9, pp. 12451246, 2001.

[188] A. Jouvenceau, L. H. Eunson, A. Spauschus et al., "Human epilepsy associated with dysfunction of the brain P/Q-type calcium channel," The Lancet, vol. 358, no. 9284, pp. 801$807,2001$.

[189] P. Imbrici, S. L. Jaffe, L. H. Eunson et al., "Dysfunction of the brain calcium channel Cav2.1 in absence epilepsy and episodic ataxia," Brain, vol. 127, no. 12, pp. 2682-2692, 2004.

[190] A. Escayg, M. de Waard, D. D. Lee et al., "Coding and noncoding variation of the human calcium-channel $\beta 4$ subunit gene CACNB4 in patients with idiopathic generalized epilepsy and episodic ataxia," American Journal of Human Genetics, vol. 66, no. 5, pp. 1531-1539, 2000.

[191] H. Khosravani, C. Altier, B. Simms et al., "Gating effects of mutations in the Cav3.2 T-type calcium channel associated with childhood absence epilepsy," Journal of Biological Chemistry, vol. 279, no. 11, pp. 9681-9684, 2004.

[192] A. Carré, G. Szinnai, M. Castanet et al., "Five new TTF1/NKX2.1 mutations in brain-lung-thyroid syndrome: rescue by PAX8 synergism in one case," Human Molecular Genetics, vol. 18, no. 12, pp. 2266-2276, 2009.

[193] L. Guillot, A. Carré, G. Szinnai et al., "NKX2-1 mutations leading to surfactant protein promoter dysregulation cause interstitial lung disease in 'brain-lung-thyroid syndrome," Human Mutation, vol. 31, no. 2, pp. E1146-E1162, 2010.

[194] G. Kleiner-Fisman, E. Rogaeva, W. Halliday et al., "Benign hereditary chorea: clinical, genetic, and pathological findings," Annals of Neurology, vol. 54, no. 2, pp. 244-247, 2003.

[195] G. Kleiner-Fisman and A. E. Lang, "Benign hereditary chorea revisited: a journey to understanding," Movement Disorders, vol. 22, no. 16, pp. 2297-2305, 2007. 
[196] M. I. Morasso and N. Radoja, "Dlx genes, p63, and ectodermal dysplasias," Birth Defects Research C, vol. 75, no. 3, pp. 163-171, 2005.

[197] N. L. Iacono, S. Mantero, A. Chiarelli et al., "Regulation of $D l x 5$ and Dlx6 gene expression by p63 is involved in EEC and SHFM congenital limb defects," Development, vol. 135, no. 7, pp. 1377-1388, 2008.

[198] A. Tagariello, R. Heller, A. Greven et al., "Balanced translocation in a patient with craniosynostosis disrupts the SOX6 gene and an evolutionarily conserved non-transcribed region," Journal of Medical Genetics, vol. 43, no. 6, pp. 534540, 2006.

[199] F. H. Yu, M. Mantegazza, R. E. Westenbroek et al., "Reduced sodium current in GABAergic interneurons in a mouse model of severe myoclonic epilepsy in infancy," Nature Neuroscience, vol. 9, no. 9, pp. 1142-1149, 2006.

[200] M. S. Martin, K. Dutt, L. A. Papale et al., "Altered function of the SCN1A voltage-gated sodium channel leads to $\gamma$ aminobutyric acid-ergic (GABAergic) interneuron abnormalities," Journal of Biological Chemistry, vol. 285, no. 13, pp. 9823-9834, 2010.

[201] G. Friocourt, S. Kanatani, H. Tabata et al., "Cell-autonomous roles of ARX in cell proliferation and neuronal migration during corticogenesis," The Journal of Neuroscience, vol. 28, no. 22, pp. 5794-5805, 2008.

[202] G. Friocourt, K. Poirier, S. Rakić, J. G. Parnavelas, and J. Chelly, "The role of ARX in cortical development," European Journal of Neuroscience, vol. 23, no. 4, pp. 869-876, 2006.

[203] G. Friocourt and J. G. Parnavelas, "Mutations in ARX result in several defects involving GABAergic neurons," Frontiers in Cellular Neuroscience, vol. 4, article 4, 2010.

[204] K. Poirier, H. van Esch, G. Friocourt et al., "Neuroanatomical distribution of ARX in brain and its localisation in GABAergic neurons," Molecular Brain Research, vol. 122, no. 1, pp. 35-46, 2004

[205] G. Colasante, P. Collombat, V. Raimondi et al., "Arx is a direct target of Dlx2 and thereby contributes to the tangential migration of GABAergic interneurons," The Journal of Neuroscience, vol. 28, no. 42, pp. 10674-10686, 2008.

[206] M. G. Price, J. W. Yoo, D. L. Burgess et al., "A triplet repeat expansion genetic mouse model of infantile spasms syndrome, $\operatorname{Arx}^{(\mathrm{GCG}) 10+7}$, with interneuronopathy, spasms in infancy, persistent seizures, and adult cognitive and behavioral impairment," The Journal of Neuroscience, vol. 29, no. 27, pp. 8752-8763, 2009.

[207] E. Marsh, C. Fulp, E. Gomez et al., "Targeted loss of Arx results in a developmental epilepsy mouse model and recapitulates the human phenotype in heterozygous females," Brain, vol. 132, no. 6, pp. 1563-1576, 2009.

[208] F. Mari, S. Azimonti, I. Bertani et al., "CDKL5 belongs to the same molecular pathway of MeCP2 and it is responsible for the early-onset seizure variant of Rett syndrome," Human Molecular Genetics, vol. 14, no. 14, pp. 1935-1946, 2005.

[209] I. Bertani, L. Rusconi, F. Bolognese et al., "Functional consequences of mutations in CDKL5, an X-linked gene involved in infantile spasms and mental retardation," Journal of Biological Chemistry, vol. 281, no. 42, pp. 32048-32056, 2006.

[210] X. Nan, H. H. Ng, C. A. Johnson et al., "Transcriptional repression by the methyl-CpG-binding protein MeCP2 involves a histone deacetylase complex," Nature, vol. 393, no. 6683, pp. 386-389, 1998.

[211] X. Nan and A. Bird, "The biological functions of the methylCpG-binding protein $\mathrm{MeCP} 2$ and its implication in Rett syndrome," Brain and Development, vol. 23, no. 1, pp. S32S37, 2001.

[212] J. L. Noebels and R. L. Sidman, "Inherited epilepsy: spikewave and focal motor seizures in the mutant mouse tottering," Science, vol. 204, no. 4399, pp. 1334-1336, 1979.

[213] C. F. Fletcher, C. M. Lutz, T. N. O’Sullivan et al., "Absence epilepsy in tottering mutant mice is associated with calcium channel defects," Cell, vol. 87, no. 4, pp. 607-617, 1996.

[214] Y. Zhang, M. Mori, D. L. Burgess, and J. L. Noebels, "Mutations in high-voltage-activated calcium channel genes stimulate low-voltage-activated currents in mouse thalamic relay neurons," The Journal of Neuroscience, vol. 22, no. 15, pp. 6362-6371, 2002.

[215] E. Tsakiridou, L. Bertollini, M. de Curtis, G. Avanzini, and H. C. Pape, "Selective increase in T-type calcium conductance of reticular thalamic neurons in a rat model of absence epilepsy," The Journal of Neuroscience, vol. 15, no. 4, pp. 31103117, 1995.

[216] D. L. Burgess, J. M. Jones, M. H. Meisler, and J. L. Noebels, "Mutation of the $\mathrm{Ca}^{2+}$ channel $\beta$ subunit gene Cchb4 is associated with ataxia and seizures in the lethargic $(l h)$ mouse," Cell, vol. 88, no. 3, pp. 385-392, 1997.

[217] D. W. Cope, G. Di Giovanni, S. J. Fyson et al., "Enhanced tonic GABAA inhibition in typical absence epilepsy," Nature Medicine, vol. 15, pp. 1392-1398, 2009.

[218] S. A. Anderson, D. D. Eisenstat, L. Shi, and J. L. R. Rubenstein, "Interneuron migration from basal forebrain to neocortex: dependence on Dlx genes," Science, vol. 278, no. 5337, pp. 474-476, 1997.

[219] A. Bulfone, F. Wang, R. Hevner et al., "An olfactory sensory map develops in the absence of normal projection neurons or GABAergic interneurons," Neuron, vol. 21, no. 6, pp. 12731282, 1998.

[220] I. Cobos, U. Borello, and J. L. R. Rubenstein, "Dlx transcription factors promote migration through repression of axon and dendrite growth," Neuron, vol. 54, no. 6, pp. 873-888, 2007.

[221] I. Cobos, M. E. Calcagnotto, A. J. Vilaythong et al., "Mice lacking Dlx1 show subtype-specific loss of interneurons, reduced inhibition and epilepsy," Nature Neuroscience, vol. 8, no. 8, pp. 1059-1068, 2005.

[222] L. Sussel, O. Marin, S. Kimura, and J. L. R. Rubenstein, "Loss of Nkx2.1 homeobox gene function results in a ventral to dorsal molecular respecification within the basal telencephalon: evidence for a transformation of the pallidum into the striatum," Development, vol. 126, no. 15, pp. 3359$3370,1999$.

[223] E. Azim, D. Jabaudon, R. M. Fame, and J. D. MacKlis, "SOX6 controls dorsal progenitor identity and interneuron diversity during neocortical development," Nature Neuroscience, vol. 12, no. 10, pp. 1238-1247, 2009.

[224] M. Le Bon-Jego and R. Yuste, "Persistently active, pacemakerlike neurons in neocortex," Frontiers in Neuroscience, vol. 1, no. 1, pp. 123-129, 2007.

[225] X. Xu, K. D. Roby, and E. M. Callaway, "Mouse cortical inhibitory neuron type that coexpresses somatostatin and calretinin," Journal of Comparative Neurology, vol. 499, no. 1, pp. 144-160, 2006.

[226] X. Xu, K. D. Roby, and E. M. Callaway, "Immunochemical characterization of inhibitory mouse cortical neurons: three chemically distinct classes of inhibitory cells," Journal of Comparative Neurology, vol. 518, no. 3, pp. 389-404, 2010.

[227] J. T. Porter, B. Cauli, J. F. Staiger, B. Lambolez, J. Rossier, and E. Audinat, "Properties of bipolar VIPergic interneurons and 
their excitation by pyramidal neurons in the rat neocortex," European Journal of Neuroscience, vol. 10, no. 12, pp. 36173628, 1998.

[228] L. Acsády, D. Arabadzisz, and T. F. Freund, "Correlated morphological and neurochemical features identify different subsets of vasoactive intestinal polypeptide-immunoreactive interneurons in rat hippocampus," Neuroscience, vol. 73, no. 2, pp. 299-315, 1996.

[229] N. Hajos, L. Acsady, and T. F. Freund, "Target selectivity and neurochemical characteristics of VIP-immunoreactive interneurons in the rat dentate gyrus," European Journal of Neuroscience, vol. 8, no. 7, pp. 1415-1431, 1996.

[230] C. Dávid, A. Schleicher, W. Zuschratter, and J. F. Staiger, "The innervation of parvalbumin-containing interneurons by VIP-immunopositive interneurons in the primary somatosensory cortex of the adult rat," European Journal of Neuroscience, vol. 25, no. 8, pp. 2329-2340, 2007.

[231] X. Xu and E. M. Callaway, "Laminar specificity of functional input to distinct types of inhibitory cortical neurons," The Journal of Neuroscience, vol. 29, no. 1, pp. 70-85, 2009.

[232] A. Karagiannis, T. Gallopin, C. Dávid et al., "Classification of NPY-expressing neocortical interneurons," The Journal of Neuroscience, vol. 29, no. 11, pp. 3642-3659, 2009.

[233] S. Olah, G. Komlosi, J. Szabadics et al., "Output of neurogliaform cells to various neuron types in the human and rat cerebral cortex," Frontiers in Neural Circuits, vol. 1, article 4, 2007.

[234] G. Tamás, A. Lörincz, A. Simon, and J. Szabadics, "Identified sources and targets of slow inhibition in the neocortex," Science, vol. 299, no. 5614, pp. 1902-1905, 2003.

[235] S. Olah, M. Fule, G. Komlosi et al., "Regulation of cortical microcircuits by unitary GABA-mediated volume transmission," Nature, vol. 461, no. 7268, pp. 1278-1281, 2009.

[236] G. Biagini, G. Panuccio, and M. Avoli, "Neurosteroids and epilepsy," Current Opinion in Neurology, vol. 23, no. 2, pp. 170-176, 2010.

[237] J. M. Pellock, R. Hrachovy, S. Shinnar et al., "Infantile spasms: a U.S. consensus report," Epilepsia, vol. 51, no. 10, pp. 2175-2189, 2010.

[238] C. J. Price, B. Cauli, E. R. Kovacs et al., "Neurogliaform neurons form a novel inhibitory network in the hippocampal CA1 area," The Journal of Neuroscience, vol. 25, no. 29, pp. 6775-6786, 2005.

[239] A. Simon, S. Olah, G. Molnar, J. Szabadics, and G. Tamas, "Gap-junctional coupling between neurogliaform cells and various interneuron types in the neocortex," The Journal of Neuroscience, vol. 25, no. 27, pp. 6278-6285, 2005.

[240] V. Zsiros and G. Maccaferri, "Electrical coupling between interneurons with different excitable properties in the stratum lacunosum-moleculare of the juvenile CA1 rat hippocampus," The Journal of Neuroscience, vol. 25, no. 38, pp. 8686-8695, 2005.

[241] B. Cauli, X. K. Tong, A. Rancillac et al., "Cortical GABA interneurons in neurovascular coupling: relays for subcortical vasoactive pathways," The Journal of Neuroscience, vol. 24, no. 41, pp. 8940-8949, 2004.

[242] B. Cauli and E. Hamel, "Revisiting the role of neurons in neurovascular coupling," Frontiers in Neuroenergetics, vol. 2, article 9, 2010.

[243] S. Anderson, M. Mione, K. Yun, and J. L. R. Rubenstein, "Differential origins of neocortical projection and local circuit neurons: role of Dlx genes in neocortical interneuronogenesis," Cerebral Cortex, vol. 9, no. 6, pp. 646-654, 1999.
[244] S. A. Anderson, O. Marín, C. Horn, K. Jennings, and J. L. R. Rubenstein, "Distinct cortical migrations from the medial and lateral ganglionic eminences," Development, vol. 128, no. 3, pp. 353-363, 2001.

[245] J. G. Corbin, S. Nery, and G. Fishell, "Telencephalic cells take a tangent: non-radial migration in the mammalian forebrain," Nature Neuroscience, vol. 4, no. 1, pp. 1177-1182, 2001.

[246] G. Miyoshi and G. Fishell, "GABAergic interneuron lineages selectively sort into specific cortical layers during early postnatal development," Cerebral Cortex, vol. 21, no. 4, pp. 845-852, 2011.

[247] M. H. Porteus, A. Bulfone, J. K. Liu, L. Puelles, L. C. Lo, and J. L. R. Rubenstein, "DLX-2, MASH-1, and MAP-2 expression and bromodeoxyuridine incorporation define molecularly distinct cell populations in the embryonic mouse forebrain," The Journal of Neuroscience, vol. 14, no. 11, pp. 6370-6383, 1994.

[248] S. J. Pleasure, S. Anderson, R. Hevner et al., "Cell migration from the ganglionic eminences is required for the development of hippocampal GABAergic interneurons," Neuron, vol. 28, no. 3, pp. 727-740, 2000.

[249] M. Kohwi, M. A. Petryniak, J. E. Long et al., "A subpopulation of olfactory bulb GABAergic interneurons is derived from Emx1- and Dlx5/6-expressing progenitors," The Journal of Neuroscience, vol. 27, no. 26, pp. 6878-6891, 2007.

[250] S. Casarosa, C. Fode, and F. Guillemot, "Mash1 regulates neurogenesis in the ventral telencephalon," Development, vol. 126, no. 3, pp. 525-534, 1999.

[251] M. Fogarty, M. Grist, D. Gelman, O. Marín, V. Pachnis, and N. Kessaris, "Spatial genetic patterning of the embryonic neuroepithelium generates GABAergic interneuron diversity in the adult cortex," The Journal of Neuroscience, vol. 27, no. 41, pp. 10935-10946, 2007.

[252] C. P. Wonders, L. Taylor, J. Welagen, I. C. Mbata, J. Z. Xiang, and S. A. Anderson, "A spatial bias for the origins of interneuron subgroups within the medial ganglionic eminence," Developmental Biology, vol. 314, no. 1, pp. 127136, 2008.

[253] N. Flames, R. Pla, D. M. Gelman, J. L. R. Rubenstein, L. Puelles, and O. Marín, "Delineation of multiple subpallial progenitor domains by the combinatorial expression of transcriptional codes," The Journal of Neuroscience, vol. 27, no. 36, pp. 9682-9695, 2007.

[254] Q. Xu, L. Guo, H. Moore, R. R. Waclaw, K. Campbell, and S. A. Anderson, "Sonic hedgehog signaling confers ventral telencephalic progenitors with distinct cortical interneuron fates," Neuron, vol. 65, no. 3, pp. 328-340, 2010.

[255] V. H. Sousa, G. Miyoshi, J. Hjerling-Leffler, T. Karayannis, and G. Fishell, "Characterization of Nkx6-2-derived neocortical interneuron lineages," Cerebral Cortex, vol. 19, supplement 1, pp. i1-i10, 2009.

[256] M. Grigoriou, A. S. Tucker, P. T. Sharpe, and V. Pachnis, "Expression and regulation of Lhx6 and Lhx7, a novel subfamily of LIM homeodomain encoding genes, suggests a role in mammalian head development," Development, vol. 125, no. 11, pp. 2063-2074, 1998.

[257] P. Liodis, M. Denaxa, M. Grigoriou, C. Akufo-Addo, Y. Yanagawa, and V. Pachnis, "Lhx6 activity is required for the normal migration and specification of cortical interneuron subtypes," The Journal of Neuroscience, vol. 27, no. 12, pp. 3078-3089, 2007.

[258] Y. Zhao, P. Flandin, J. E. Long, M. D. Cuesta, H. Westphal, and J. L. R. Rubenstein, "Distinct molecular pathways of 
development of telencephalic interneuron subtypes revealed through analysis of Lhx6 mutants," Journal of Comparative Neurology, vol. 510, no. 1, pp. 79-99, 2008.

[259] M. Andäng, J. Hjerling-Leffler, A. Moliner et al., "Histone $\mathrm{H} 2 \mathrm{AX}$-dependent $\mathrm{GABA}_{\mathrm{A}}$ receptor regulation of stem cell proliferation," Nature, vol. 451, no. 7177, pp. 460-464, 2008.

[260] J. J. LoTurco, D. F. Owens, M. J. S. Heath, M. B. E. Davis, and A. R. Kriegstein, "GABA and glutamate depolarize cortical progenitor cells and inhibit DNA synthesis," Neuron, vol. 15, no. 6, pp. 1287-1298, 1995.

[261] N. Heck, W. Kilb, P. Reiprich et al., "GABA-A receptors regulate neocortical neuronal migration in vitro and in vivo," Cerebral Cortex, vol. 17, no. 1, pp. 138-148, 2007.

[262] R. Tyzio, A. Represa, I. Jorquera, Y. Ben-Ari, H. Gozlan, and L. Aniksztejn, "The establishment of GABAergic and glutamatergic synapses on CA1 pyramidal neurons is sequential and correlates with the development of the apical dendrite," The Journal of Neuroscience, vol. 19, no. 23, pp. 10372-10382, 1999.

[263] S. Hennou, I. Khalilov, D. Diabira, Y. Ben-Ari, and H. Gozlan, "Early sequential formation of functional $\mathrm{GABA}_{\mathrm{A}}$ and glutamatergic synapses on CA1 interneurons of the rat foetal hippocampus," European Journal of Neuroscience, vol. 16, no. 2, pp. 197-208, 2002.

[264] E. Delpire, "Cation-chloride cotransporters in neuronal communication," News in Physiological Sciences, vol. 15, no. 6, pp. 309-312, 2000.

[265] C. Rivera, J. Voipio, J. A. Payne et al., "The $\mathrm{K}^{+} / \mathrm{Cl}^{-}$cotransporter KCC2 renders GABA hyperpolarizing during neuronal maturation," Nature, vol. 397, no. 6716, pp. 251255, 1999.

[266] H. Li, J. Tornberg, K. Kaila, M. S. Airaksinen, and C. Rivera, "Patterns of cation-chloride cotransporter expression during embryonic rodent CNS development," European Journal of Neuroscience, vol. 16, no. 12, pp. 2358-2370, 2002.

[267] J. B. Manent, M. Demarque, I. Jorquera et al., "A noncanonical release of GABA and glutamate modulates neuronal migration," The Journal of Neuroscience, vol. 25, no. 19, pp. 4755-4765, 2005.

[268] D. Bortone and F. Polleux, "KCC2 expression promotes the termination of cortical interneuron migration in a voltagesensitive calcium-dependent manner," Neuron, vol. 62, no. 1, pp. 53-71, 2009.

[269] D. D. Wang and A. R. Kriegstein, "GABA regulates excitatory synapse formation in the neocortex via NMDA receptor activation," The Journal of Neuroscience, vol. 28, no. 21, pp. 5547-5558, 2008.

[270] D. D. Wang and A. R. Kriegstein, "Blocking early GABA depolarization with bumetanide results in permanent alterations in cortical circuits and sensorimotor gating deficits," Cerebral Cortex, vol. 21, no. 3, pp. 574-587, 2011.

[271] L. Cancedda, H. Fiumelli, K. Chen, and M. M. Poo, "Excitatory GABA action is essential for morphological maturation of cortical neurons in vivo," The Journal of Neuroscience, vol. 27, no. 19, pp. 5224-5235, 2007.

[272] R. Cossart, "The maturation of cortical interneuron diversity: how multiple developmental journeys shape the emergence of proper network function," Current Opinion in Neurobiology, vol. 21, no. 1, pp. 160-168, 2010.

[273] T. K. Hensch, M. Fagiolini, N. Mataga, M. P. Stryker, S. Baekkeskov, and S. F. Kash, "Local GABA circuit control of experience-dependent plasticity in developing visual cortex," Science, vol. 282, no. 5393, pp. 1504-1508, 1998.
[274] M. Fagiolini, J. M. Fritschy, K. Low, H. Mohler, U. Rudolph,

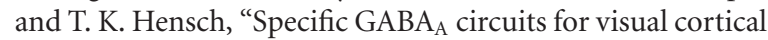
plasticity," Science, vol. 303, no. 5664, pp. 1681-1683, 2004.

[275] Y. Yazaki-Sugiyama, S. Kang, H. Cteau, T. Fukai, and T. K. Hensch, "Bidirectional plasticity in fast-spiking GABA circuits by visual experience," Nature, vol. 462, no. 7270, pp. 218-221, 2009.

[276] A. Harauzov, M. Spolidoro, G. DiCristo et al., "Reducing intracortical inhibition in the adult visual cortex promotes ocular dominance plasticity," The Journal of Neuroscience, vol. 30, no. 1, pp. 361-371, 2010.

[277] V. Crépel, D. Aronov, I. Jorquera, A. Represa, Y. Ben-Ari, and R. Cossart, "A parturition-associated nonsynaptic coherent activity pattern in the developing hippocampus," Neuron, vol. 54, no. 1, pp. 105-120, 2007.

[278] C. Allène, A. Cattani, J. B. Ackman et al., "Sequential generation of two distinct synapse-driven network patterns in developing neocortex," The Journal of Neuroscience, vol. 28, no. 48, pp. 12851-12863, 2008.

[279] Y. Ben-Ari, E. Cherubini, R. Corradetti, and J. L. Gaiarsa, "Giant synaptic potentials in immature rat CA3 hippocampal neurones," Journal of Physiology, vol. 416, pp. 303-325, 1989.

[280] P. Bonifazi, M. Goldin, M. A. Picardo et al., "GABAergic hub neurons orchestrate synchrony in developing hippocampal networks," Science, vol. 326, no. 5958, pp. 1419-1424, 2009.

[281] M. D. Lundorf, H. N. Buttenschon, L. Foldager et al., "Mutational screening and association study of glutamate decarboxylase 1 as a candidate susceptibility gene for bipolar affective disorder and schizophrenia," American Journal of Medical Genetics Part B, vol. 135, no. 1, pp. 94-101, 2005.

[282] R. Batista-Brito, R. MacHold, C. Klein, and G. Fishell, "Gene expression in cortical interneuron precursors is prescient of their mature function," Cerebral Cortex, vol. 18, no. 10, pp. 2306-2317, 2008.

[283] J. DeFelipe, "Cortical interneurons: from Cajal to 2001," Progress in Brain Research, vol. 136, pp. 215-238, 2002.

[284] P. Rakic, "Evolution of the neocortex: a perspective from developmental biology," Nature Reviews Neuroscience, vol. 10, no. 10, pp. 724-735, 2009.

[285] J. DeFelipe, "Types of neurons, synaptic connections and chemical characteristics of cells immunoreactive for calbindin-D28K, parvalbumin and calretinin in the neocortex," Journal of Chemical Neuroanatomy, vol. 14, no. 1, pp. 1-19, 1997.

[286] J. DeFelipe, L. Alonso-Nanclares, and J. I. Arellano, "Microstructure of the neocortex: comparative aspects," Journal of Neurocytology, vol. 31, no. 3-5, pp. 299-316, 2002.

[287] K. Letinic, R. Zoncu, and P. Rakic, "Origin of GABAergic neurons in the human neocortex," Nature, vol. 417, no. 6889, pp. 645-649, 2002.

[288] S. Rakic and N. Zecevic, "Emerging complexity of layer I in human cerebral cortex," Cerebral Cortex, vol. 13, no. 10, pp. 1072-1083, 2003.

[289] X. Yu and N. Zecevic, "Dorsal radial glial cells have the potential to generate cortical interneurons in human but not in mouse brain," The Journal of Neuroscience, vol. 31, no. 7, pp. 2413-2420, 2011.

[290] S. Lindsay, S. Sarma, M. Martínez-de-la-Torre et al., "Anatomical and gene expression mapping of the ventral pallium in a three-dimensional model of developing human brain," Neuroscience, vol. 136, no. 3, pp. 625-632, 2005.

[291] S. Sarma, J. Kerwin, L. Puelles et al., "3D modelling, gene expression mapping and post-mapping image analysis in the 
developing human brain," Brain Research Bulletin, vol. 66, no. 4-6, pp. 449-453, 2005.

[292] I. Jakovcevski, N. Mayer, and N. Zecevic, "Multiple origins of human neocortical interneurons are supported by distinct expression of transcription factors," Cerebral Cortex, vol. 21, no. 8, pp. 1771-1782, 2011.

[293] N. Zecevic, F. Hu, and I. Jakovcevski, "Interneurons in the developing human neocortex," Developmental Neurobiology, vol. 71, no. 1, pp. 18-33, 2011.

[294] DSM-IV, Diagnostic and Statistical Manual of Mental Disorders, American Psychiatric Association, Washington, DC, USA, 1994.

[295] B. Elvevag and T. E. Goldberg, "Cognitive impairment in schizophrenia is the core of the disorder," Critical Reviews in Neurobiology, vol. 14, no. 1, pp. 1-21, 2000.

[296] J. R. Cohen, B. Elvevåg, and T. E. Goldberg, "Cognitive control and semantics in schizophrenia: an integrated approach," American Journal of Psychiatry, vol. 162, no. 10, pp. 19691971, 2005.

[297] Z. H. Qin, S. P. Zhang, and B. Weiss, "Dopaminergic and glutamatergic blocking drugs differentially regulate glutamic acid decarboxylase mRNA in mouse brain," Molecular Brain Research, vol. 21, no. 3-4, pp. 293-302, 1994.

[298] M. Gierdalski, B. Jablonska, A. Smith, J. Skangiel-Kramska, and M. Kossut, "Deafferentation induced changes in GAD67 and GluR2 mRNA expression in mouse somatosensory cortex," Molecular Brain Research, vol. 71, no. 1, pp. 111-119, 1999.

[299] R. S. Woo, X. M. Li, Y. Tao et al., "Neuregulin-1 enhances depolarization-induced GABA release," Neuron, vol. 54, no. 4, pp. 599-610, 2007.

[300] D. W. Volk, J. N. Pierri, J. M. Fritschy, S. Auh, A. R. Sampson, and D. A. Lewis, "Reciprocal alterations in preand postsynaptic inhibitory markers at chandelier cell inputs to pyramidal neurons in schizophrenia," Cerebral Cortex, vol. 12, no. 10, pp. 1063-1070, 2002.

[301] J. G. Maldonado-Avilés, A. A. Curley, T. Hashimoto et al., "Altered markers of tonic inhibition in the dorsolateral prefrontal cortex of subjects with schizophrenia," American Journal of Psychiatry, vol. 166, no. 4, pp. 450-459, 2009.

[302] S. R. Cobb, E. H. Buhl, K. Halasy, O. Paulsen, and P. Somogyi, "Synchronization of neuronal activity in hippocampus by individual GABAergic interneurons," Nature, vol. 378, no. 6552, pp. 75-78, 1995.

[303] S. L. Smalley, P. E. Tanguay, M. Smith, and G. Gutierrez, "Autism and tuberous sclerosis," Journal of Autism and Developmental Disorders, vol. 22, no. 3, pp. 339-355, 1992.

[304] S. L. Smalley, "Autism and tuberous sclerosis," Journal of Autism and Developmental Disorders, vol. 28, no. 5, pp. 407414, 1998.

[305] J. Sebat, B. Lakshmi, D. Malhotra et al., "Strong association of de novo copy number mutations with autism," Science, vol. 316, no. 5823, pp. 445-449, 2007.

[306] R. A. Kumar, S. Karamohamed, J. Sudi et al., "Recurrent 16p11.2 microdeletions in autism," Human Molecular Genetics, vol. 17, no. 4, pp. 628-638, 2008.

[307] C. R. Marshall, A. Noor, J. B. Vincent et al., "Structural variation of chromosomes in autism spectrum disorder," American Journal of Human Genetics, vol. 82, no. 2, pp. 477488, 2008.

[308] L. A. Weiss, Y. Shen, J. M. Korn et al., "Association between microdeletion and microduplication at 16p11.2 and autism," The New England Journal of Medicine, vol. 358, no. 7, pp. 667675,2008 .
[309] M. W. State, "The genetics of child psychiatric disorders: focus on autism and tourette syndrome," Neuron, vol. 68, no. 2, pp. 254-269, 2010.

[310] S. Lim, S. Naisbitt, J. Yoon et al., "Characterization of the Shank family of synaptic proteins: multiple genes, alternative splicing, and differential expression in brain and development," Journal of Biological Chemistry, vol. 274, no. 41, pp. 29510-29518, 1999.

[311] A. A. Chubykin, X. Liu, D. Comoletti, I. Tsigelny, P. Taylor, and T. C. Südhof, "Dissection of synapse induction by neuroligins: effect of a neuroligin mutation associated with autism," Journal of Biological Chemistry, vol. 280, no. 23, pp. 22365-22374, 2005.

[312] G. Dölen, R. L. Carpenter, T. D. Ocain, and M. F. Bear, "Mechanism-based approaches to treating fragile X," Pharmacology and Therapeutics, vol. 127, no. 1, pp. 78-93, 2010.

[313] A. Brooks-Kayal, "Epilepsy and autism spectrum disorders: are there common developmental mechanisms?" Brain and Development, vol. 32, no. 9, pp. 731-738, 2010.

[314] A. Yasuhara, "Correlation between EEG abnormalities and symptoms of autism spectrum disorder (ASD)," Brain and Development, vol. 32, no. 10, pp. 791-798, 2010.

[315] N. C. de Lanerolle, J. H. Kim, R. J. Robbins, and D. D. Spencer, "Hippocampal interneuron loss and plasticity in human temporal lobe epilepsy," Brain Research, vol. 495, no. 2, pp. 387-395, 1989.

[316] P. Marco, R. G. Sola, P. Pulido et al., "Inhibitory neurons in the human epileptogenic temporal neocortex: an immunocytochemical study," Brain, vol. 119, no. 4, pp. 1327-1347, 1996.

[317] L. Wittner, Z. Magloczky, Z. Borhegyi et al., "Preservation of perisomatic inhibitory input of granule cells in the epileptic human dentate gyrus," Neuroscience, vol. 108, no. 4, pp. 587600, 2001.

[318] L. A. Jansen, L. D. Peugh, and J. G. Ojemann, "GABA receptor properties in catastrophic infantile epilepsy," Epilepsy Research, vol. 81, no. 2-3, pp. 188-197, 2008.

[319] I. Cohen, V. Navarro, S. Clemenceau, M. Baulac, and R. Miles, "On the origin of interictal activity in human temporal lobe epilepsy in vitro," Science, vol. 298, no. 5597, pp. 14181421, 2002.

[320] I. Khalilov, G. L. Holmes, and Y. Ben-Ari, "In vitro formation of a secondary epileptogenic mirror focus by interhippocampal propagation of seizures," Nature Neuroscience, vol. 6, no. 10, pp. 1079-1085, 2003.

[321] R. S. Sloviter, "Decreased hippocampal inhibition and a selective loss of interneurons in experimental epilepsy," Science, vol. 235, no. 4784, pp. 73-76, 1987.

[322] R. S. Sloviter, "Permanently altered hippocampal structure, excitability, and inhibition after experimental status epilepticus in the rat: the "dormant basket cell" hypothesis and its possible relevance to temporal lobe epilepsy," Hippocampus, vol. 1, no. 1, pp. 41-66, 1991.

[323] D. H. Lowenstein, M. J. Thomas, D. H. Smith, and T. K. McIntosh, "Selective vulnerability of dentate hilar neurons following traumatic brain injury: a potential mechanistic link between head trauma and disorders of the hippocampus," The Journal of Neuroscience, vol. 12, no. 12, pp. 4846-4853, 1992.

[324] P. S. Buckmaster and A. L. Jongen-Rêlo, "Highly specific neuron loss preserves lateral inhibitory circuits in the dentate gyrus of kainate-induced epileptic rats," The Journal of Neuroscience, vol. 19, no. 21, pp. 9519-9529, 1999. 
[325] C. Dinocourt, Z. Petanjek, T. F. Freund, Y. Ben-Ari, and M. Esclapez, "Loss of interneurons innervating pyramidal cell dendrites and axon initial segments in the CA1 region of the hippocampus following pilocarpine-induced seizures," Journal of Comparative Neurology, vol. 459, no. 4, pp. 407425, 2003.

[326] N. C. de Lanerolle, J. H. Kim, A. Williamson et al., "A retrospective analysis of hippocampal pathology in human temporal lobe epilepsy: evidence for distinctive patient subcategories," Epilepsia, vol. 44, no. 5, pp. 677-687, 2003.

[327] A. Andrioli, L. Alonso-Nanclares, J. I. Arellano, and J. DeFelipe, "Quantitative analysis of parvalbumin-immunoreactive cells in the human epileptic hippocampus," Neuroscience, vol. 149, no. 1, pp. 131-143, 2007.

[328] J. DeFelipe, "Chandelier cells and epilepsy," Brain, vol. 122, no. 10, pp. 1807-1822, 1999.

[329] J. I. Arellano, A. Muñoz, I. Ballesteros-Yáñez, R. G. Sola, and J. DeFelipe, "Histopathology and reorganization of chandelier cells in the human epileptic sclerotic hippocampus," Brain, vol. 127, no. 1, pp. 45-64, 2004.

[330] U. Sayin, S. Osting, J. Hagen, P. Rutecki, and T. Sutula, "Spontaneous seizures and loss of axo-axonic and axosomatic inhibition induced by repeated brief seizures in kindled rats," The Journal of Neuroscience, vol. 23, no. 7, pp. 2759-2768, 2003.

[331] E. A. van Vliet, E. Aronica, E. A. Tolner, F. H. Lopes da Silva, and J. A. Gorter, "Progression of temporal lobe epilepsy in the rat is associated with immunocytochemical changes in inhibitory interneurons in specific regions of the hippocampal formation," Experimental Neurology, vol. 187, no. 2, pp. 367-379, 2004.

[332] L. Palm, G. Blennow, and A. Brun, "Infantile spasms and neuronal heterotopias: a report on six cases," Acta Paediatrica Scandinavica, vol. 75, no. 5, pp. 855-859, 1986.

[333] K. Jellinger, "Neuropathological aspects of infantile spasms," Brain and Development, vol. 9, no. 4, pp. 349-357, 1987.

[334] H. V. Vinters, M. J. de Rosa, M. A. Farrell, P. Genton, A. Portera-Sanchez, and C. K. Benninger, "Neuropathologic study of resected cerebral tissue from patients with infantile spasms," Epilepsia, vol. 34, no. 4, pp. 772-779, 1993.

[335] M. Hayashi, "Neuropathology of the limbic system and brainstem in West syndrome," Brain and Development, vol. 23, no. 7, pp. 516-522, 2001.

[336] R. Riikonen, "Long-term outcome of patients with West syndrome," Brain and Development, vol. 23, no. 7, pp. 683687, 2001.

[337] L. A. Jansen, L. D. Peugh, W. H. Roden, and J. G. Ojemann, "Impaired maturation of cortical $\mathrm{GABA}_{\mathrm{A}}$ receptor expression in pediatric epilepsy," Epilepsia, vol. 51, no. 8, pp. 1456-1467, 2010.

[338] L. Claes, B. Ceulemans, D. Audenaert et al., "De novo SCN1A mutations are a major cause of severe myoclonic epilepsy of infancy," Human Mutation, vol. 21, no. 6, pp. 615-621, 2003.

[339] K. Kanai, S. Hirose, H. Oguni et al., "Effect of localization of missense mutations in SCN1A on epilepsy phenotype severity," Neurology, vol. 63, no. 2, pp. 329-334, 2004.

[340] K. Kanai, S. Yoshida, S. Hirose et al., "Physicochemical property changes of amino acid residues that accompany missense mutations in SCN1A affect epilepsy phenotype severity," Journal of Medical Genetics, vol. 46, no. 10, pp. 671679, 2009.

[341] I. Ogiwara, H. Miyamoto, N. Morita et al., "Na 1.1 localizes to axons of parvalbumin-positive inhibitory interneurons: a circuit basis for epileptic seizures in mice carrying an Scnla gene mutation," The Journal of Neuroscience, vol. 27, no. 22, pp. 5903-5914, 2007.

[342] E. H. Sherr, "The ARX story (epilepsy, mental retardation, autism, and cerebral malformations): one gene leads to many phenotypes," Current Opinion in Pediatrics, vol. 15, no. 6, pp. 567-571, 2003.

[343] L. Rusconi, L. Salvatoni, L. Giudici et al., "CDKL5 expression is modulated during neuronal development and its subcellular distribution is tightly regulated by the C-terminal tail," Journal of Biological Chemistry, vol. 283, no. 44, pp. 3010130111, 2008.

[344] L. M. Dibbens, H. J. Feng, M. C. Richards et al., "GABRD encoding a protein for extra- or peri- synaptic $G_{A B A}$ receptors is susceptibility locus for generalized epilepsies," Human Molecular Genetics, vol. 13, no. 13, pp. 1315-1319, 2004.

[345] Y. Chen, J. Lu, H. Pan et al., "Association between genetic variation of CACNA1H and childhood absence epilepsy," Annals of Neurology, vol. 54, no. 2, pp. 239-243, 2003.

[346] D. L. Burgess and J. L. Noebels, "Single gene defects in mice: the role of voltage-dependent calcium channels in absence models," Epilepsy Research, vol. 36, no. 2-3, pp. 111-122, 1999.

[347] E. M. Talley, G. Solórzano, A. Depaulis, E. Perez-Reyes, and D. A. Bayliss, "Low-voltage-activated calcium channel subunit expression in a genetic model of absence epilepsy in the rat," Molecular Brain Research, vol. 75, no. 1, pp. 159-165, 2000.

[348] P. Smits, P. Li, J. Mandel et al., "The transcription factors L-Sox5 and Sox6 are essential for cartilage formation," Developmental Cell, vol. 1, no. 2, pp. 277-290, 2001.

[349] P. Smits and V. Lefebvre, "Sox5 and Sox6 are required for notochord extracellular matrix sheath formation, notochord cell survival and development of the nucleus pulposus of intervertebral discs," Development, vol. 130, no. 6, pp. 11351148, 2003.

[350] P. Smits, P. Dy, S. Mitra, and V. Lefebvre, "Sox5 and Sox6 are needed to develop and maintain source, columnar, and hypertrophic chondrocytes in the cartilage growth plate," Journal of Cell Biology, vol. 164, no. 5, pp. 747-758, 2004.

[351] S. C. Baraban, D. G. Southwell, R. C. Estrada et al., "Reduction of seizures by transplantation of cortical GABAergic interneuron precursors into Kv1.1 mutant mice," Proceedings of the National Academy of Sciences of the United States of America, vol. 106, no. 36, pp. 15472-15477, 2009.

[352] J. Y. Sebe and S. C. Baraban, "The promise of an interneuronbased cell therapy for epilepsy," Developmental Neurobiology, vol. 71, no. 1, pp. 107-117, 2011. 

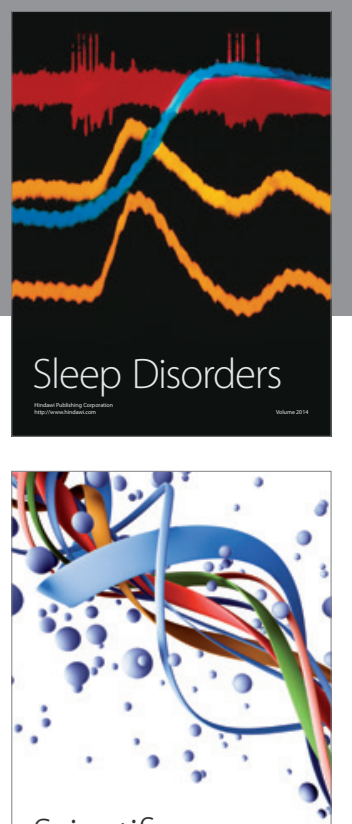

Scientifica
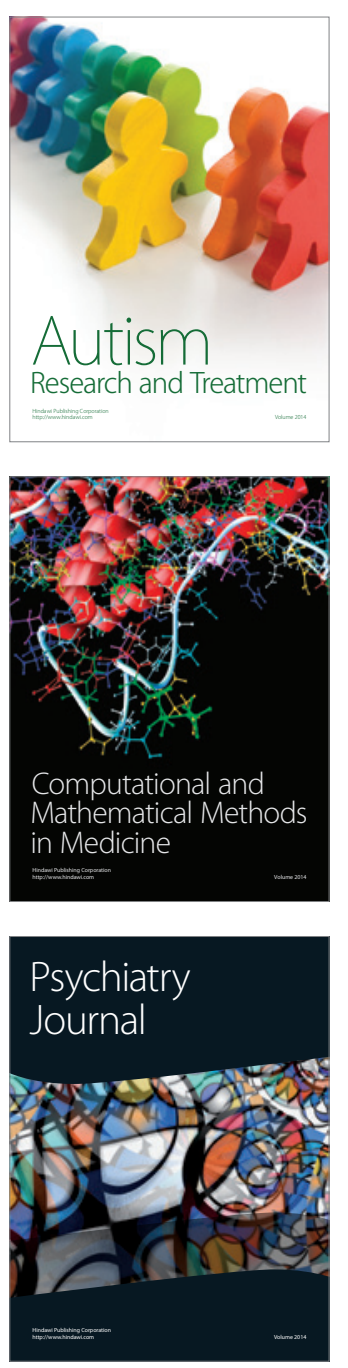
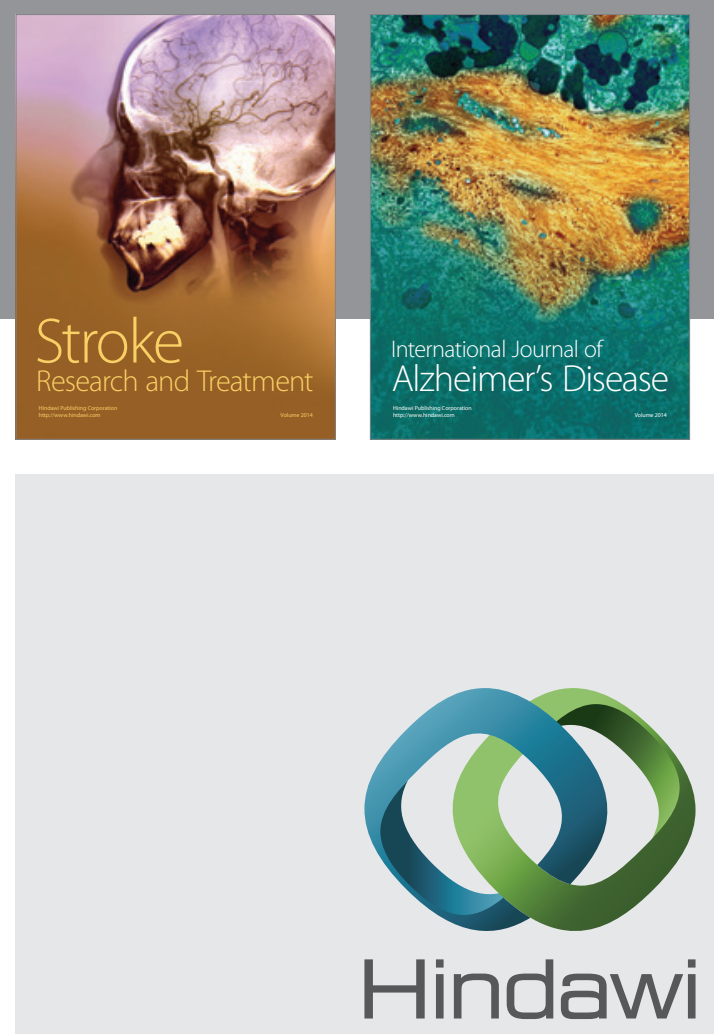

Submit your manuscripts at

http://www.hindawi.com
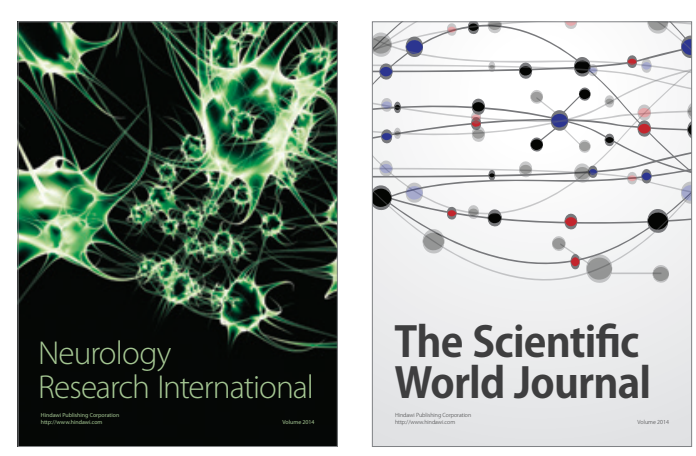

The Scientific World Journal

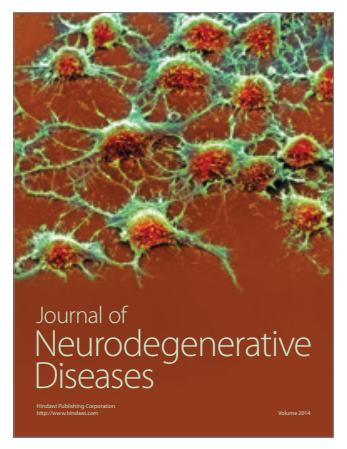

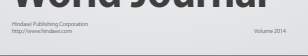

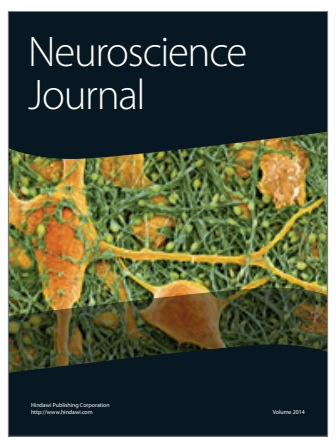

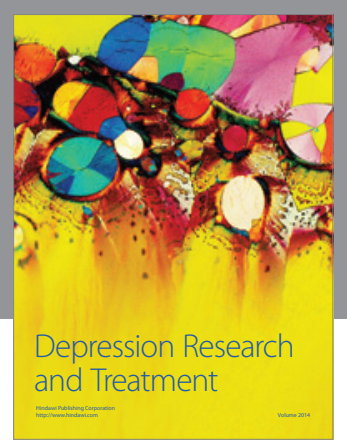
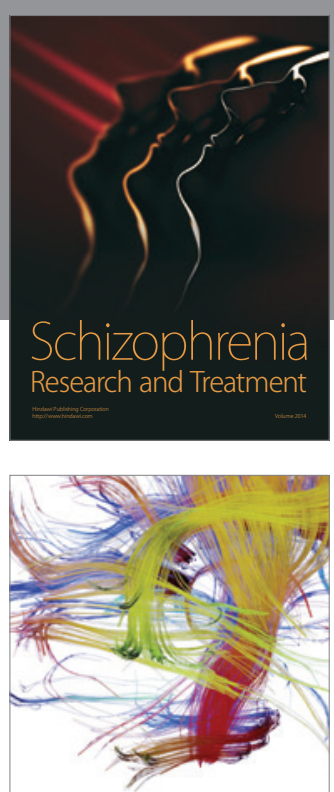

Brain Science

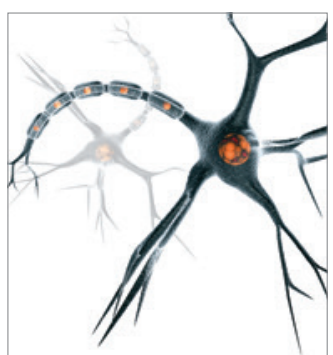

Neural Plasticity
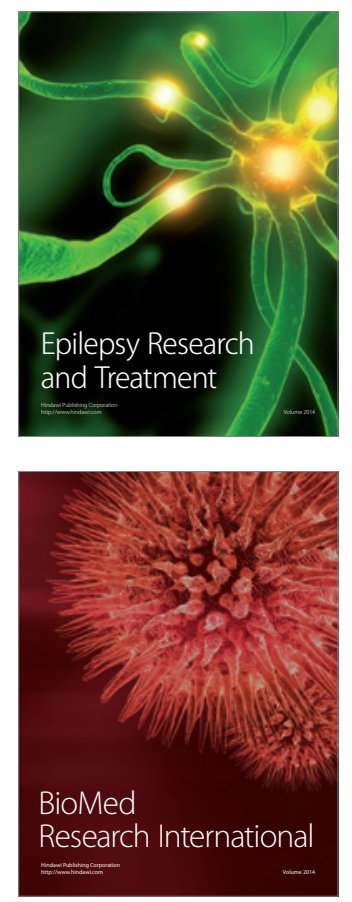

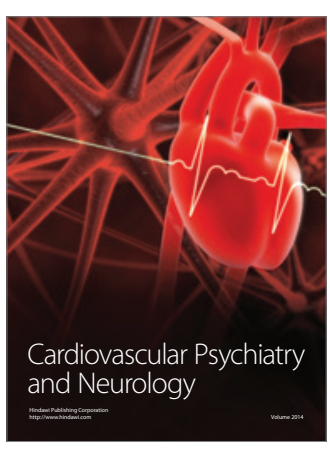

Parkinson's

Disease
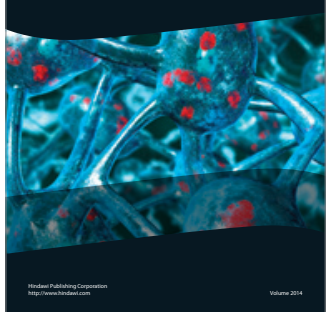